AperTO - Archivio Istituzionale Open Access dell'Università di Torino

Palaeoenvironmental significance of sponge spicules in pre-Messinian crisis sediments, Northern Italy

This is a pre print version of the following article:

Original Citation:

Availability:

This version is available http://hdl.handle.net/2318/1770202

since 2021-01-30T18:48:43Z

Published version:

DOI:10.1007/s10347-020-00619-4

Terms of use:

Open Access

Anyone can freely access the full text of works made available as "Open Access". Works made available under a Creative Commons license can be used according to the terms and conditions of said license. Use of all other works requires consent of the right holder (author or publisher) if not exempted from copyright protection by the applicable law. 


\title{
Palaeoenvironmental significance of sponge spicules in pre-Messinian crisis sediments, Northern Italy
}

\author{
Gabriele Costa ${ }^{1}$ (1) $\cdot$ Giorgio Bavestrello ${ }^{1} \cdot$ Riccardo Cattaneo-Vietti $^{1} \cdot$ Francesco Dela Pierre $^{2} \cdot$ Francesca Lozar $^{2}$. \\ Marcello Natalicchio ${ }^{2} \cdot$ Donata Violanti $^{2} \cdot$ Maurizio Pansini ${ }^{1} \cdot$ Antonietta Rosso $^{3} \cdot$ Marco Bertolino $^{1}$
}

Received: 6 October 2020 / Accepted: 12 December 2020

(c) Springer-Verlag GmbH Germany, part of Springer Nature 2021

\begin{abstract}
The Messinian Salinity Crisis (MSC) created a substantial negative impact on the Mediterranean marine fauna and flora because hypersaline conditions were established in many marginal basins. At the northern margin of the Tertiary Piedmont Basin, Northern Italy, the Messinian successions exposed at Banengo and Moncalvo recorded the transition into and through the MSC with well-preserved nanno-, micro- and macrofossils. Siliceous sponge spicules present in these pre-MSC sediments reflect the sponge population in this area with twenty different morphological types of spicule identified, twelve of them attributable to sponge genera of the modern Mediterranean sponge fauna. The most common genera were Stelletta, Geodia and Dercitus, with fewer records of Tethya, Chondrilla, Alectona and Samus. Only two types of spicule belong to species not currently present in the Mediterranean sponge fauna and are putatively attributed to the tropical species Stelletta purpurea and Diplastrella megastellata. The sponge assemblage thriving before the onset of the MSC provided new information on the sponge diversity and palaeoenvironment of this northern sector of the palaeo-Mediterranean basin over this crucial period. These data, integrated with information derived from the associated fossils (nannofossils, benthic and planktic foraminifers, and bryozoans), indicate that the considered sites were coastal localities, with sediments rich in an organic matter likely derived from phytoplankton blooms. At both sites, the presence of patchy rocky substrates on the seafloor is testified by a diversified group of sponges typical of hard substrata. These rocks were, very likely, carbonate as suggested by the presence of spicules of typical boring sponges. In the studied sites, common epiphytic foraminifers and bryozoan segments indicate the presence of Posidonia seagrass or algal meadows.
\end{abstract}

Keywords Messinian Salinity Crisis $\cdot$ Tertiary Piedmont Basin $\cdot$ Porifera $\cdot$ Spicules

\section{Introduction}

Many Mediterranean marine benthic organisms suffered a substantial negative impact during the Messinian Salinity Crisis (MSC), a dramatic palaeoceanographic event which occurred between 5.97 and 5.33 Ma ago (Hsü et al. 1973; Cita et al. 1978; Suc et al. 1995; Krijgsman et al. 1999; Blanc-Valleron et al. 2002; Merle et al. 2002; Kouwenhoven

Gabriele Costa

gabrielec1987@gmail.com

1 DISTAV, Università degli Studi di Genova, Corso Europa 26, 16132 Genova, Italy

2 Dipartimento di Scienze della Terra, via Valperga Caluso 35, 10135 Torino, Italy

3 Dipartimento di Scienze Biologiche, Geologiche e Ambientali, Corso Italia, 57, 95129 Catania, Italy et al. 2006; Wade and Bown 2006; Morigi et al. 2007; Lozar et al. 2010; Violanti et al. 2013; Manzi et al. 2013; Flecker et al. 2015; Lozar et al. 2018; Sabino et al. 2020; Hoffmann et al. 2020 inter alii). The sharp reduction of water exchange between the Mediterranean Sea and the Atlantic Ocean finally led to the onset of the MSC in the late Messinian resulting in the deposition of large quantities of evaporites (Roveri et al. 2014).

The Messinian events in the Mediterranean region start with a pre-evaporitic stage, documented by laminated sediments deposited in deeper-water settings, showing a clear precessional rhythm controlled lithological pattern and recording the progressive reduction of oxygen and decreased circulation on the seafloor. Following this, the three-fold subdivision of the MSC succession comprises: (1) an evaporitic stage with the deposition of the Lower Evaporites in marginal basins and shales in the deeper basins; (2) a 
second stage with Resedimented Lower Evaporites and (3) the post-evaporitic Lago-Mare deposits, including brackish and continental deposits, and the Upper Evaporites. In the Northern Apennines, the Messinian succession consists of this subdivision (Roveri et al. 1998, 2004) which is well preserved and chronologically dated (Krijgsman et al. 1999); moreover, the same subdivision has also been recognised in the Tertiary Piedmont Basin (TPB).

During the first stage of the MSC, gypsum deposition in intermediate and deeper-water settings was delayed by tens of thousands of years in marginal locations (Manzi et al. 2007; Dela Pierre et al. 2011; Gennari et al. 2013; Violanti et al. 2013; Lozar et al. 2018 inter alii). In the TPB succession, the hemipelagic sediments of the Sant'Agata Fossili Marls (SAF), show, in their upper part, a lithological cyclicity of shale/marl couplets and in some sites also carbonaterich beds; this cyclic succession represents the pre-evaporitic stage and the basal part of stage 1 (Irace et al. 2005; Dela Pierre et al. 2011, 2014). The SAF yield well preserved calcareous microfossils, more abundant and diversified in the pre-MSC levels (Violanti et al. 2007, 2013; Lozar et al. 2010, 2018), whereas siliceous microfossils, mainly diatoms (Bonci et al. 1991; Bonci 1995; Pellegrino et al. 2020a, b), radiolarians and siliceous sponge spicules are rarely found.

In Italy, significant amounts of siliceous sponges were reported from the Eocene of Veneto (Matteucci and Russo 2005; Frisone et al. 2014), the upper Miocene of the Tertiary Piedmont Basin (Bonci et al. 1996), and from several other Miocene to Pleistocene localities of the northern and central Apennines and Sardinia (see Matteucci and Russo 2012, and references therein). Common to abundant siliceous sponge spicules were also found in the microfossil assemblages of the upper cycles of the SAF, on the northern margin of the TPB, in the Banengo and Moncalvo sections where a succession of pre-evaporitic and evaporitic sediments is preserved (Lozar et al. 2018).

In the uppermost SAF cycles of Banengo and Moncalvo, a distinct succession of calcareous microfossil bioevents occurred: (i) a prominent peak of the coccolith Sphenolithus abies Deflandre in Deflandre and Fert, 1954 followed or accompanied by (ii) peaks of Helicosphaera carteri (Wallich, 1877) Kamptner, 1954, Rhabdosphaera procera Martini, 1969 and Umbilicosphaera spp.; (iii) an influx of the foraminifers Globorotalia scitula (Brady, 1882) and Globorotalia suterae Catalano and Sprovieri, 1971, and (iv) the disappearance of planktic foraminifers $>125 \mu \mathrm{m}$. These bioevents have been used as a reliable tool to recognise the onset of the MSC on a Mediterranean Basin scale (Lozar et al. 2018). From a palaeoenvironmental point of view, this succession of bioevents shows that the reduction in water exchange with the Atlantic Ocean at the MSC onset increased the sensitivity of the Mediterranean Sea to freshwater input and associated nutrient delivery, and culminated in a further increase in marine productivity (Mancini et al. 2020). Moreover, common to abundant bryozoan fragments, never previously reported from the Messinian of Piedmont, were observed in the same layers of the uppermost SAF of the two sections.

The presence of rich sponge assemblages in pre-MSC sediments of the TPB was investigated in detail in this study with the objectives: (1) to describe the different types of siliceous sponge spicule preserved in the Banengo and Moncalvo sediments and document the diversity of the sponge assemblage at the onset of MSC, (2) to explore possible relationships with the recent Mediterranean sponge fauna, and (3) to reconstruct the likely palaeoenvironment, using sponges and associated fossils, including nannofossils, benthic and planktic foraminifers, and bryozoans.

\section{Materials and methods}

Samples containing the fossil spicules of siliceous sponges were collected from the northern margin of the TPB (Fig. 1) in the Banengo and Moncalvo sections, which preserve the boundary between the Sant'Agata Fossil Marls (SAF) and the evaporites of the Primary Lower Gypsum unit and record the onset of the MSC. Detailed analyses of the calcareous nanno- and microfossils, in support of the sponge spicules study, were carried out on the same sedimentary section; 11 samples (cycles Bm3 and Bm4) were collected from the Banengo section and seven samples (cycles $\mathrm{Mm} 2$ and $\mathrm{Mm} 3$ ) from the Moncalvo section (see details in Lozar et al. 2018).

\section{Banengo section}

The Banengo section comprises the upper part of the SAF Marls and four cycles of the Primary Lower Gypsum (PLG). Following Lozar et al. (2018), the lithological cycles belonging to the SAF consist of laminated shale-massive marl couplets $(\mathrm{Bm} 1-\mathrm{Bm} 5)$ and are $2-3 \mathrm{~m}$ thick; the laminated shale is up to $1 \mathrm{~m}$ thick, whereas the massive marls are $1-2 \mathrm{~m}$ thick. The overlying PLG cycles consist of four shalegypsum cycles formed of massive selenite facies (Bernardi 2013), i.e. dm-sized vertically-oriented selenite crystals with uniform size throughout the beds (Dela Pierre et al. 2015). In the upper cycle, the massive selenite grades upwards to banded selenite, consisting of palisades of $\mathrm{cm}$-sized twinned crystals separated by thin clay veneers. Shale semi-couplets of the PLG cycles are up to $3 \mathrm{~m}$ thick and show a prominent lamination, resulting from the alternation of clay and carbonate-rich laminae; the gypsum layers are up to $30 \mathrm{~m}$ thick. Siliceous sponge spicules were common to abundant in layers of the Bm3 and Bm4 cycles (Lozar et al. 2018). 


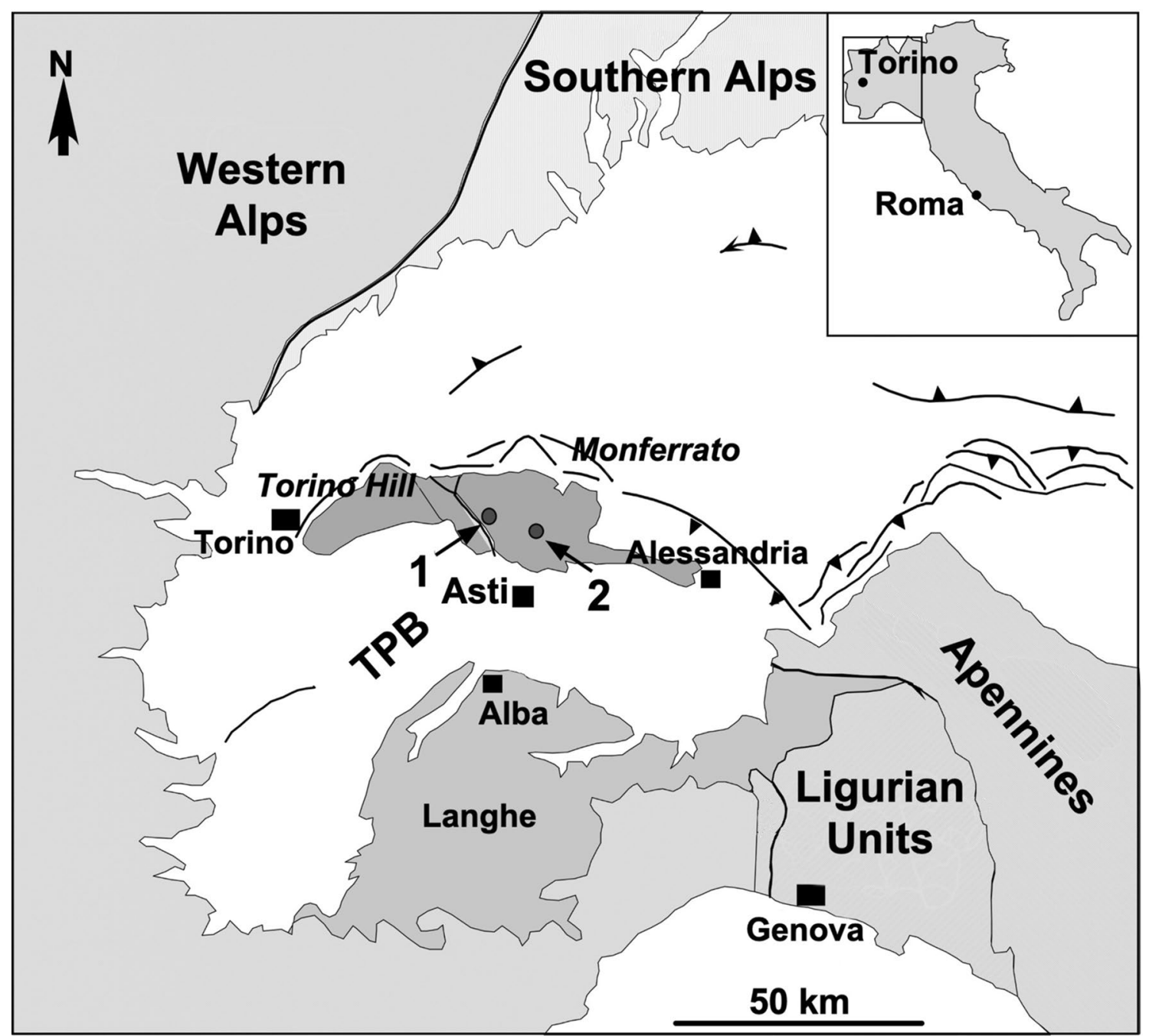

Fig. 1 Schematic geological map of the central Piedmont region. TPB Tertiary Piedmont Basin. Numbers indicate the location of the studied sections: (1) Banengo, (2) Moncalvo

\section{Moncalvo section}

Moncalvo is a composite section studied by Lozar et al. (2018), integrating core and outcrop data. The cored succession starts with $5 \mathrm{~m}$, representing the uppermost four lithological cycles of the SAF and is capped by the first gypsum cycle. Each SAF cycle consists of grey laminated shale and light grey massive-homogeneous marl (Mm1Mm4). The lower three PLG cycles consist of a $1 \mathrm{~m}$ thick grey muddy layer, overlain by about $10 \mathrm{~m}$ thick gypsum beds composed of the massive selenite facies (Bernardi 2013; Lozar et al. 2018) and dm-sized bottom grown selenite crystals. The gypsum bed of the fourth cycle records distinctive branching selenite facies, allowing the correlation to the Sturani Key Bed recognised in the Alba region and locally representing the 6th PLG cycle (Dela Pierre et al. 2011).

\section{Age model}

Calcareous microfossils of the SAF marls studied from Banengo, and Moncalvo (Lozar et al. 2018) can be correlated to the Messinian foraminiferal subzone MMi13c of Lourens et al. (2004) and the calcareous nannofossil zone MNN11b/c of Raffi et al. (2003). The two sections were correlated to the Pollenzo section (Lozar et al. 2010, 2018; Dela Pierre et al. 2011; Violanti et al. 2013), by the highest common occurrence of Turborotalita multiloba (Romeo, 1965), dated to an age-range between 6.04 and $6.08 \mathrm{Ma}$, and by the MSC calcareous nannofossil bioevents (the $S$. abies peak, together with the G. scitula and G. suterae influx, and the disappearance of planktic foraminifers $>125 \mu \mathrm{m}$ ) (Lozar et al. 2018; Lozar and Negri 2019; Mancini et al. 2020), which approximate to the MSC onset across the basin. The foraminifer and calcareous nannofossil bioevents also 
provide a reliable correlation to the Mediterranean reference sections (Sierro et al. 2001; Blanc-Valleron et al. 2002; Gennari et al. 2018).

\section{Micropalaeontological content}

Calcareous nannofossils and very small planktic foraminifers are recorded in the cycles of the SAF, above the onset of the MSC. In the laminated shale and massive marl couplets of the upper SAF cycles, diatoms, radiolarians, siliceous sponge spicules and bryozoans, fish debris, plant frustules and rare mollusc and echinoid fragments also occur. Sponge spicules and bryozoans are abundant in some samples of the $\mathrm{Bm} 3$ and $\mathrm{Bm} 4$ cycles at Banengo, and $\mathrm{Mm} 2$ and $\mathrm{Mm} 3$ cycles at Moncalvo. In the uppermost samples of the Moncalvo sections, only siliceous microfossils (diatoms, radiolarians, and sponge spicules), fish and plant debris are preserved (Lozar et al. 2018). All studied samples belong to cycles Bm3-4 (Banengo section) and cycles Mm2-3 (Moncalvo section) (see details in Lozar et al. 2018).

\section{Spicule analysis}

Four samples were selected for the analysis of the sponge assemblage due to their abundant spicule content: two from Banengo (samples BG 7.2 and BG 8.1) and two from Moncalvo (samples MC $130.70 \mathrm{~m}$ and MC $131.10 \mathrm{~m}$ ) sections, shown with a red hyphen, respectively in Figs. 10 and Fig. 11.

Spicules were analysed following the method proposed by Bertolino et al. $(2014 ; 2017)$. For each sample, $0.05 \mathrm{~g}$ of sediment were mounted on five microscope slides $(0.01 \mathrm{~g}$ each). The microscopic analysis allowed the identification and sizing of each sponge spicule present in the slides. For scanning electron microscope (SEM) analysis, a further portion of $0.05 \mathrm{~g}$ of sediment was treated with hydrogen peroxide (240 vol), rinsed twice in distilled water, twice in alcohol $95^{\circ}$, dried, mounted on to stubs, sputter-coated with gold and observed under SEM Vega3 TESCAN Microscope type LMU at the DISTAV (Università degli Studi di Genova) laboratory.

Whenever possible, the spicules were attributed to a putative genus or identified to the lowest possible taxonomic level. In the analysis, it was postulated that, at a first approximation, the spicule amount in the sediments reflected the sponge abundance in the palaeoenvironment.

\section{Calcareous nannofossils}

Standard smear-slides were prepared for each sample and observed at $1250 \mathrm{X}$ in polarised light. For quantitative analysis, a total of 500 specimens were counted from each sample. Abundances of very rare selected taxa (Discoaster spp.,
Amaurolithus spp.) were determined by counting $4.5 \mathrm{~mm}^{2}$ on each slide. In the studied samples, calcareous nannofossils $(\mathrm{CN})$ are well to moderately preserved. In the Banengo samples, calcareous nannofossils were abundant to common, whereas the group showed a lower abundance in the Moncalvo samples (Lozar et al. 2018).

\section{Foraminifers and bryozoans}

For foraminiferal and bryozoan analyses, about $150 \mathrm{~g}$ of dry sediment were disaggregated with hydrogen peroxide, gently washed on a set of 250,125 , and $63 \mu \mathrm{m}$ sieves, dried and weighted. Percentages of planktic and benthic foraminiferal taxa were calculated on the total $>125 \mu \mathrm{m}$ residue, eventually split into fractions yielding about 300 specimens.

Bryozoan fragments were collected from the $>250 \mu \mathrm{m}$ fraction. Residues also yielded few fragments or very small bivalve shells, scarce ostracods, very rare echinoids and fish debris, and abundant to scarce plant frustules. Radiolarians were recovered only in sample 130.70, Moncalvo section.

\section{Results}

\section{Sponge spicules}

SEM analysis showed that most of the spicules are broken and with the typical dissolution signs, having the surface incised by sub-circular marks that locally developed into tunnels reaching the commonly enlarged axial canal. In general, microscleres, such as sterrasters and aspidasters, were better preserved, probably due to their small size which makes them less prone to mechanical breakage; megacleres on the other hand, showed numerous holes, in some cases coalescent along the axis, and numerous tips were missing. The rhabdomes of the large orthotriaenes were commonly broken, having enlarged axial canals (Fig. 2).

From a quantitative point of view, the richest sample was Moncalvo MC 131.10 with about 14,000 spicules/g of sediment, whereas sample MC 130.70 showed a spicule content lower by about one order of magnitude. In Banengo, samples BG 7.2 and BG 8.1 showed a similar spicule amount (1450 and 2660 spicules/g, respectively) (Fig. 3). Among the twenty types of spicule recorded, the more common (calthrops, plagiotriaenes, and sterrasters) can be attributed respectively to the genera Dercitus Gray, 1867, Stelletta Schmidt, 1862 and Geodia Lamarck, 1815 (Table 1).

\section{Calthrops and dichotriaenes of genus Dercitus Gray, 1867}

The fossil calthrops (equiangular tetraxons with equal rays) and short-shafted dichotriaenes (ortho- or plagiotriaenes in 


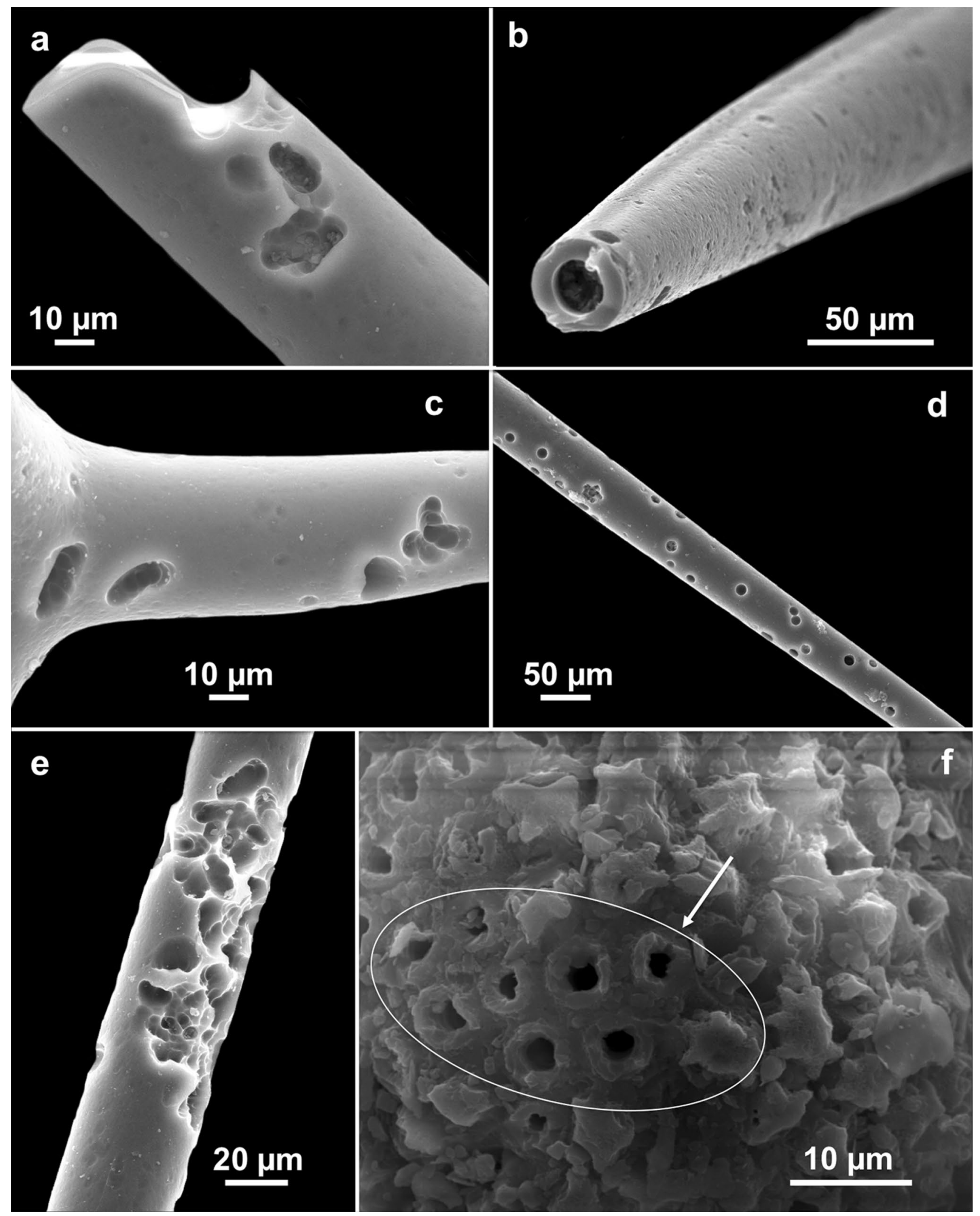

Fig. 2 Dissolution evidence: $\mathbf{a}, \mathbf{b}, \mathbf{d}$ pits in the spicule surface; $\mathbf{b}$ enlarged axial canal; e, $\mathbf{f}$ Different levels of dissolution in the sterrasters of Geodia 


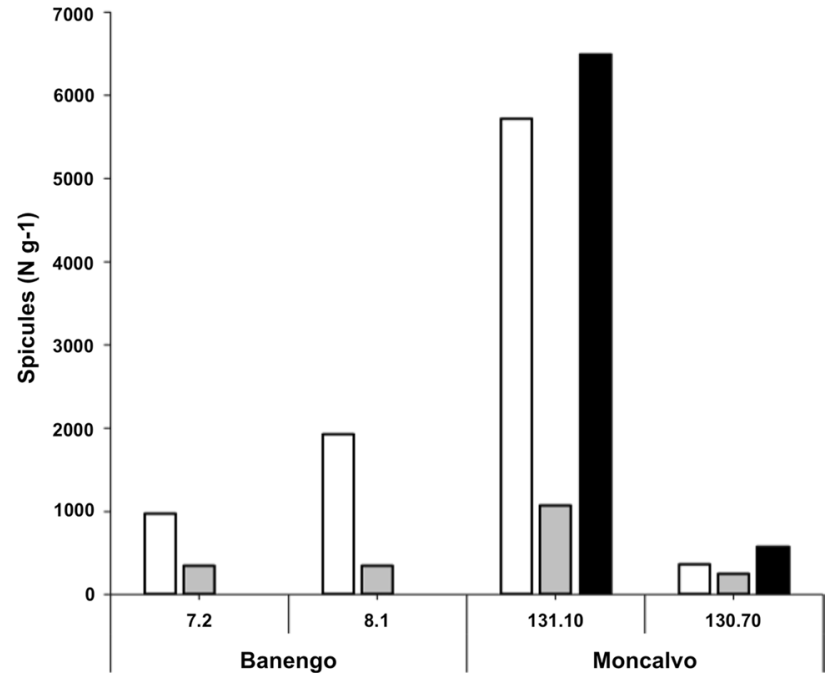

Fig. 3 Spicule abundance of the main sponge taxa in individual samples of the two considered sites. White bars, Stelletta sp.; grey bars, Dercitus sp.; black bars, Geodia sp

which the clade bifurcated) (Fig. 4a) are spicules referable to the genus Dercitus. These spicule types are present in both localities with very similar amounts. The size-frequency distributions of the lengths of the clades of calthrops, in both localities, widely overlap (Fig. 5a), suggesting that they belong to the same species.
Three extant species belonging to this genus, Dercitus (Stoeba) dissimilis (Sarà, 1959), D. (Stoeba) lesinensis (von Lendenfeld 1894) and D. (Stoeba) plicatus (Schmidt, 1868) are present in the Mediterranean Sea. Based on shape and size, our fossil spicules can be ascribed to D. (Stoeba) plicatus, a common species, today mainly recorded on coastal rocky outcrops.

\section{Plagio-, ortho- and anatriaenes of genus Stelletta Schmidt, 1862}

In the samples of both sites, numerous plagiotriaenes and much rarer orto- and anatriaenes were found. Plagiotriaenes are characterised by straight to slightly curved rhabdomes and clades ending with a pointed tip (Fig. 4b, c). The rhabdomes of these spicules were commonly broken. They correspond to the typical Stelletta spicules and are very similar to those found by Frisone et al. (2014) in the Eocene of the Lessini Mountains, by Łukowiak et al. (2014) in the lower Miocene of Slovakia and by Pisera et al. (2006) in the Miocene of Portugal. The shape and size of our fossil spicules (Fig. 4c) are similar to those of the recent Stelletta dorsigera Schmidt, 1864 (see Lendenfeld 1890), today commonly present on the Mediterranean sandy and muddy seafloors. Furthermore, very particular triaenes, with a rhabdome in some cases very short and stout, characterised by a swollen end, were observed
Table 1 The relative abundance of the fossil spicules in the two considered sites are indicated (+rare, ++ present, +++ abundant, ++++ very abundant, -- absent). The spicules are putatively related to current taxa and their growth habits

\begin{tabular}{llllll}
\hline Spicule type & Length $(\mu \mathrm{m})$ & \multicolumn{2}{l}{ Relative abundance } & Putative taxon & Growth habit \\
\cline { 2 - 3 } & & Moncalvo & Banengo & \\
\hline sterrasters & $60-170$ & ++++ & - & Geodia & massive \\
anathriaenes & $700-850$ & +++ & ++ & Geodia/Stelletta & massive \\
plagiotriaenes & $220-2,700$ & ++++ & ++++ & Stelletta & massive \\
orthotriaenes & $680-750$ & + & ++ & Stelletta & massive \\
chaltrops & $30-360$ & +++ & ++ & Dercitus & massive/cavity dwelling \\
dichotriaenes & $190-210$ & ++ & +++ & Dercitus & massive/cavity dwelling \\
strongyloxeas & $800-1,400$ & ++ & ++ & Tethya $?$ & massive \\
spheroxiasters & $60-70$ & + & -- & Tethya & massive \\
tuberculate oxeas & 250 & + & + & Alectona & boring \\
spherasters & $20-25$ & + & - & Chondrilla & massive \\
amphitriaenes & 120 & - & + & Samus & cavity dwelling \\
tylotes & 306 & + & -- & Antho (Plocamia $)$ & massive \\
anisochaelae & 110 & + & -- & Mycale & massive \\
anthospheraster & $51-92$ & + & + & Diplastrella & encrusting \\
aspidasters & $90-163$ & + & + & Erylinae & massive/cavity dwelling \\
styles & $500-900$ & + & + & Axinellidae & massive/erect \\
strongyles & 850 & + & ++ & Petrosiidae & massive \\
tylostyles & broken & + & ++ & Suberitidae & massive \\
oxeas & $1150-3500$ & ++ & ++ & Tetractinellida & massive \\
desmas & broken & + & + & Lithistid sponges & massive/encrusting \\
\hline & & & & &
\end{tabular}


(Figs. 4d and 6a-c). Similar trianes with short rhabdome and swollen end, called prodichotriaene, were recorded by Łukowiak et al. (2019) from the Eocene of Ukraine. Stelletta purpurea Ridley, 1884, from the Red Sea and the Indo-Pacific Ocean, shows these particular spicules, 1-2 mm long (Dendy, 1905; Thomas, 1979), congruent with our fossil material. Moreover, Thiele (1900) reported deformed spicules with modified cladome for $S$. purpurea, like those recorded in our material (Fig. 4e). Spicules with this unusual morphology but longer (2.5-3.4 mm long) occur in Ancorina cerebrum Schmidt, 1862 from the present-day Mediterranean.

\section{Sterrasters of genus Geodia Lamarck, 1815}

The observed fossil sterrasters had a spherical to ellipsoidal shape in which the rays were fused and ended in stellate terminations, with details locally obscured by different levels of corrosion (Fig. 7a). According to van Soest et al. (2012), nearly $95 \%$ of recent sponges bearing sterrasters belong to the genus Geodia. The attribution of our abundant sterrasters to this genus is also supported by the simultaneous presence of anatriaenes, typical of the family Geodiidae Gray, 1867 (Fig. 7b). These spicules represented the most abundant type in sample MC 131.10 of Moncalvo with about 6,500 spicules/g, reduced by one order of magnitude in sample MC 130.70. Their presence was negligible in both Banengo samples.

The analysis of the size-frequency distribution of the sterrasters' diameters showed a bimodal distribution in the classes: 70-80 and 120-130 $\mu \mathrm{m}$ in each sample (Fig. 5b).

The Geodia sterrasters from Moncalvo show a diameter smaller than those from the late Miocene of Cappella Montei (Alessandria, Piedmont) found by Bonci et al. (1996), having a main mode centred in class 150-160 $\mu \mathrm{m}$ and a secondary one in class 190-200 $\mu \mathrm{m}$ (Fig. 5b). Spicules from Cappella Montei have sizes similar to those coming from the middle Eocene of the Lessini Mountains (Frisone et al. 2014), as well as those illustrated in Łukowiak et al. (2014) from the Miocene of Slovakia and those of Geodia avicula Brimaud and Vachard 1986 from the Miocene of Spain (Brimaud and Vachard 1986).

Sterrasters in the 70-80 $\mu \mathrm{m}$ mode, have sizes comparable to those of a group of recent Mediterranean species such as $G$. anceps (Vosmaer, 1894), G. cydonium (Linnaeus, 1767), G. micropunctata Row, 1911 and $G$. tuberosa Schmidt, 1862. Among them, G. cydonium is the most common species, occurring mainly between 0.5 and
$45 \mathrm{~m}$ water depth, on sandy seafloors. Sterrasters in the 120-130 $\mu \mathrm{m}$ mode are comparable with those of the extant G. barretti Bowerbank, 1858, G. conchilega Schmidt, 1862 and $G$. pachydermata (Sollas, 1886).

\section{Other spicule types}

In both studied localities, several other types of siliceous spicule were more rarely found. The recorded spheroxyasters (Fig. 6d) are typical of the genus Tethya Lamarck, 1815. Very likely also the long strongyloxeas belong to this genus (Fig. 8a). In view of their long rays, the spheroxyasters match with the current $T$. citrina Sarà $\&$ Melone, 1965, often recorded in Mediterranean coastal areas.

Aspidasters referable to the subfamily Erylinae Sollas, 1888 were recorded at Moncalvo. They have a flattened and ovoid-like shape, and their rays are fused and covered by minute spinose projections (Fig. 8b). Aspidaster spicules (Fig. 6g) presently occur also in the widespread Mediterranean species Penares euastrum (Schmidt, 1868).

In the Banengo samples, a few basically symmetrical amphitriaenes with $120 \mu \mathrm{m}$ long ray were found (Fig. 6k). They can be related to the recent Samus anonymus Gray, 1867, a cavity-dwelling species recorded in limestone and other calcareous bioconstructions. Amphitriaenes of Samus were already described by Łukowiak et al. (2014) from the Miocene of Slovakia.

Tuberculate oxeas (Fig. 8c) were also recorded, similar to those of the present-day species of the genus Alectona Carter, 1879. They are acerate and sharply curved or slightly bent in the centre, covered by tubercles arranged in longitudinal rows. The shape and size (about $250 \mu \mathrm{m}$ ) of these spicules are comparable with those of Alectona millari Carter, 1879 which is the only species of the genus present today in the Mediterranean Sea. The few spherasters (Fig. 6e) can be attributed to Chondrilla nucula Schmidt, 1862, the only species of this genus in the Mediterranean. The large anthospherasters (Fig. 6f) are similar to the spicules characterising the living Diplastrella megastellata Hechtel, 1965 from the Caribbean. Regarding poecilosclerid sponges, some tylotes of Antho (Plocamia) spp. (Fig. 61) and anisochelae of Mycale spp. (Fig. 6i) were recorded at Moncalvo.

The short, stout, curved styles (Fig. 8d) are similar to those described by Hinde and Holmes (1892) from the Cenozoic of New Zealand and may belong to several species of the family Axinellidae, currently abundant in the Mediterranean Sea. The rare strongyles (Fig. 6j) probably 

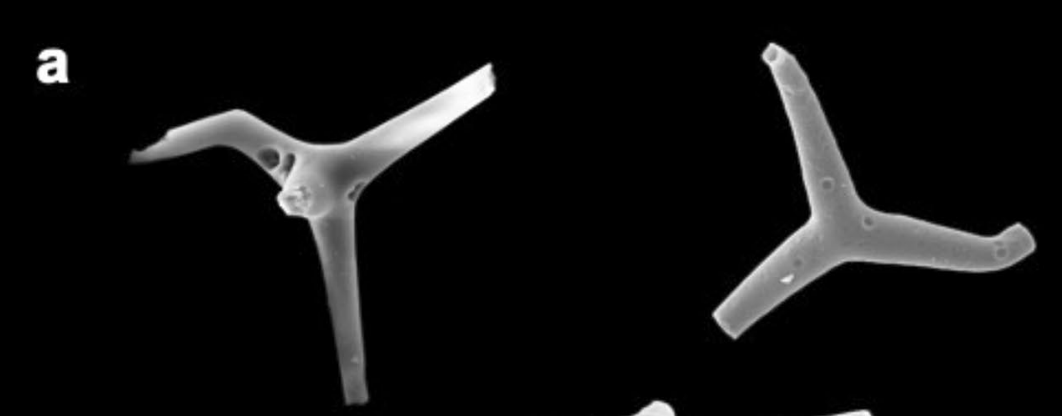

100 pm
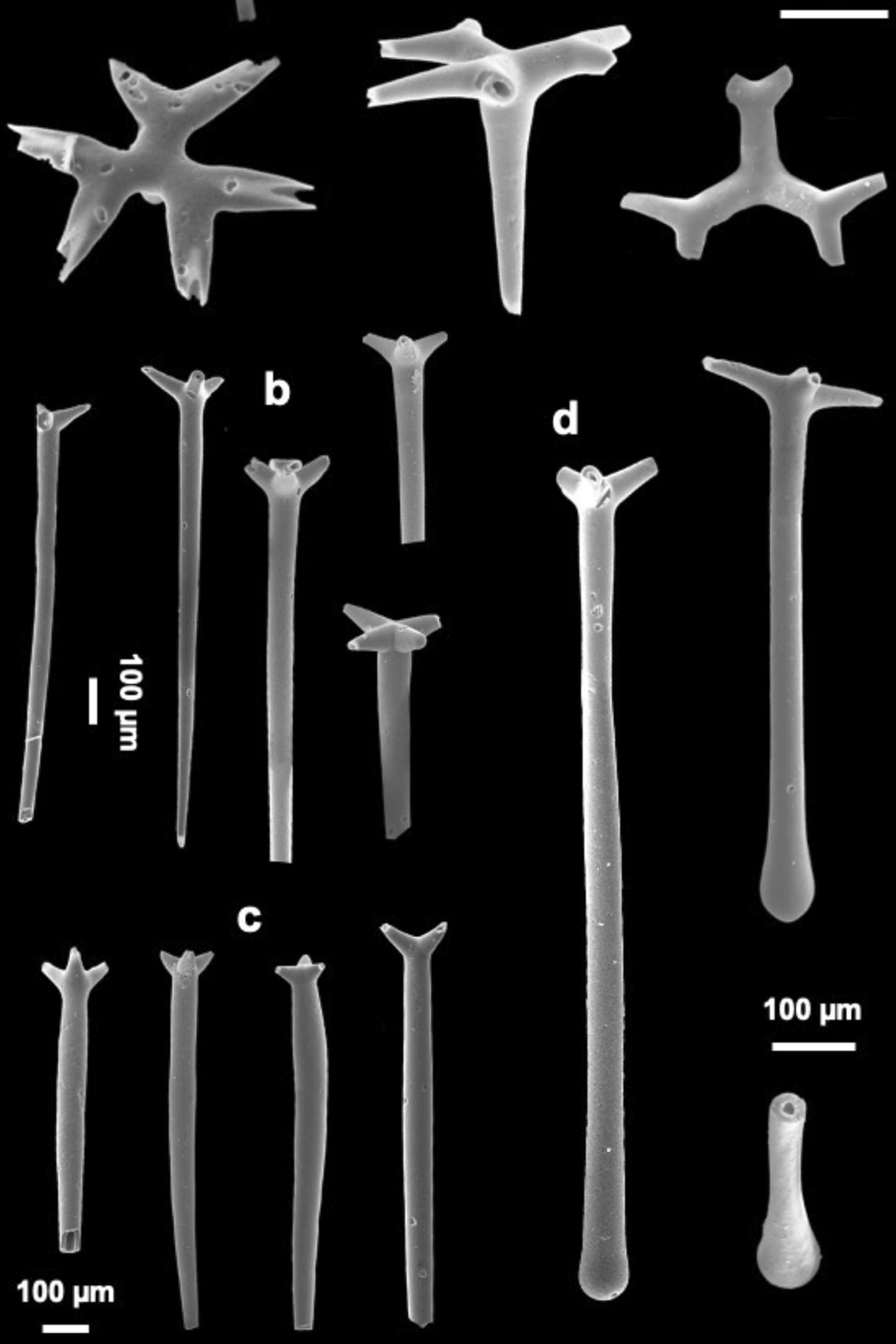

C
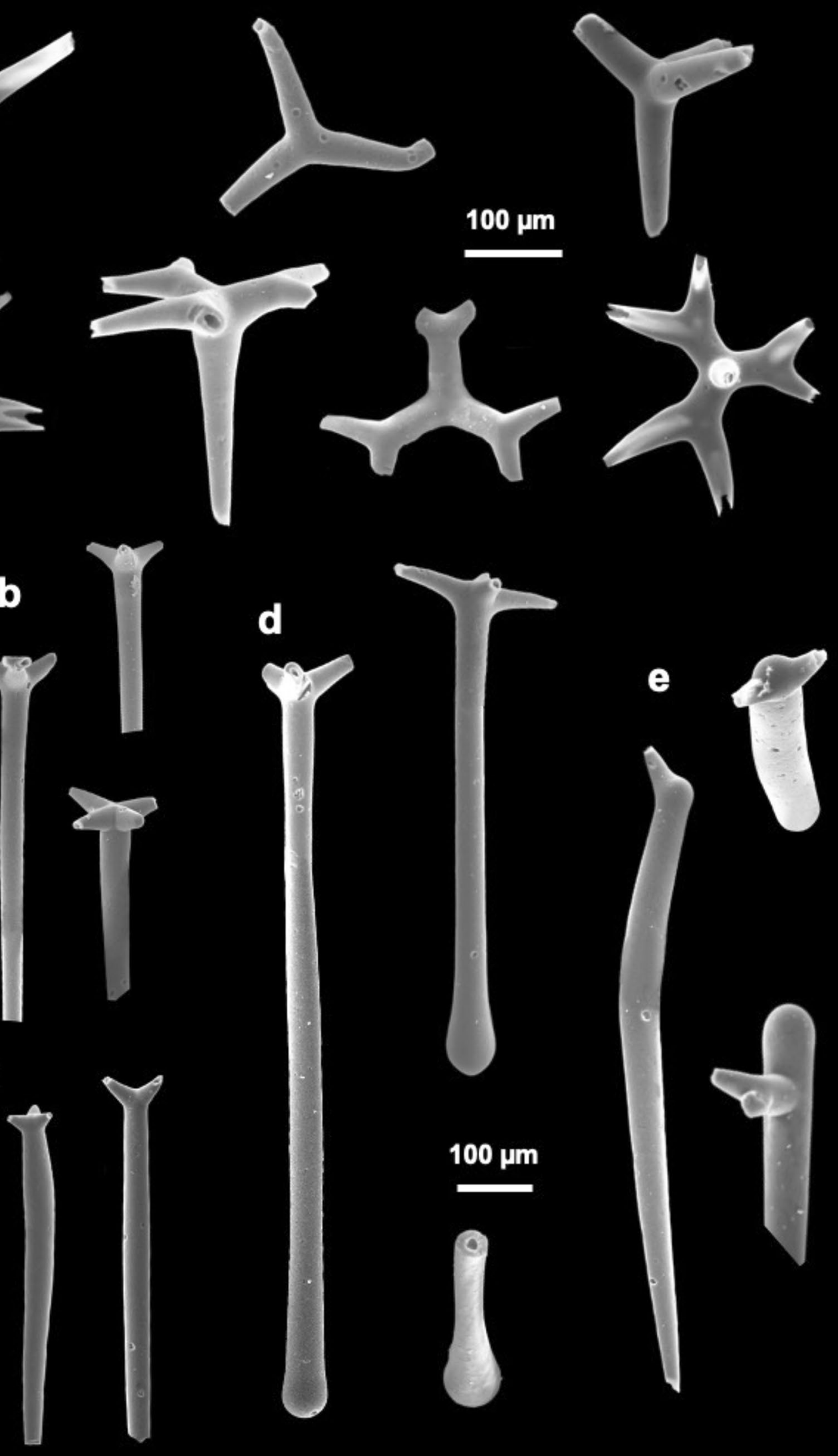
4Fig. 4 Spicules found in the Messinian samples of the Piedmont Basin: a calthrops and dichotriaenes of Dercitus; b orthotriaenes of Stelletta; c plagiotriaenes congruent with those of the recent Stelletta dorsigera; d peculiar orthotriaene of Stelletta; e "deformed" spicules congruent with those of the recent Stelletta purpurea

belong to species of the family Petrosiidae van Soest, 1980. Some tylostyles (Fig. 8e), sporadically recorded in the Moncalvo material, can be attributed to the family Suberitidae Schmidt, 1870, whereas some large oxeas (Fig. 8f), due to their size, can be attributed to the order Tetractinellida. Finally, several desmas, referable to the lithistid sponge group, were found in both localities (Fig. 6h).

\section{Calcareous nannofossils}

Calcareous nannofossil assemblages of both sections (Figs. 9, 10a and 11a) contained a diverse flora dominated by the coccoliths Reticulofenestra minuta Roth, 1970, together with Coccolithus pelagicus (Wallich 1877) Schiller, 1930, Calcidiscus leptoporus (Murray and Blackman 1898) Loeblich and Tappan, 1978, and Reticulofenestra antarctica (Wade and Bown 2006). Minor components of the assemblage were Helicosphaera carteri, Umbilicosphaera jafari Muller, 1974 and Umbilicosphaera rotula (Kamptner, 1956) Varol, 1982. Lower photic zone taxa, such as Sphenolithus spp. and Discoaster spp., were very rare, but $S$. abies was somehow more abundant in the MSC bioevent (Moncalvo $\mathrm{Mm} 3$ cycle). This assemblage has been described in several sections across the Mediterranean basin and points to a eutrophic water column dominated in the upper photic zone by opportunistic taxa (Reticulofenestra spp.) and by eutrophic and low salinity water taxa (C. pelagicus, $R$. antarctica).

\section{Foraminifers}

At Banengo, planktic foraminifers, always represented by small or very small tests, were rather common in the shales and marls of cycle Bm3, absent or very rare in the cycle Bm4 (Lozar et al. 2018). Turborotalita quinqueloba (Natland, 1938), a still-living cool-water eutrophic taxon (Hemleben et al. 1989), was commonly the dominant planktic form (Figs. 9 and 10b). T. multiloba, a Messinian species (Iaccarino, 1985), occurred in the upper cycle Bm3. Very rare G. scitula and G. suterae, also interpreted as cool-water
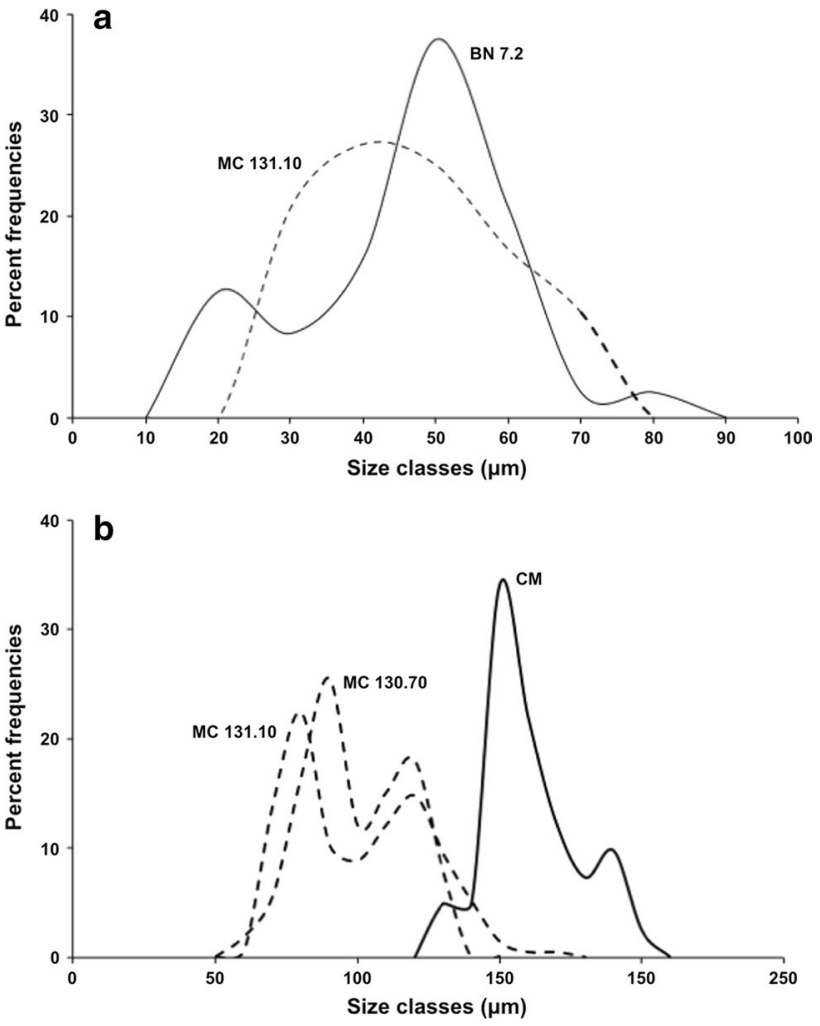

Fig. 5 a Size-frequency distribution of the lengths of the clades of calthrops of Dercitus from Moncalvo 131.10 (dashed line) and Banengo 7.2 (continuous line); $\mathbf{b}$ analysis of the size-frequency distributions of the Geodia sterrasters from Moncalvo 131.10 and 130.70 (dashed lines) in comparison with those from the Late Miocene of Cappella Montei (continuous line) (Bonci et al. 1996)

eutrophic forms (Violanti et al. 2013; Lozar et al. 2018), were recorded in the uppermost cycle Bm 4.

Among the benthic foraminifers (Figs. 9 and 10b), Bolivina spp. [grouping Bolivina pseudoplicata Heron-Allen and Earland, 1930, Brizalina arta (Macfadyen, 1930), Brizalina dentellata (Tavani, 1955), Brizalina dilatata (Reuss, 1850) and Brizalina spathulata (Williamson, 1858)], infaunal stress-tolerant taxa typical of muddy shelf seafloors (Murray 2006), were abundant to common. Bulimina echinata d'Orbigny, 1852, probably an opportunistic eutrophic species well adapted to the peculiar palaeoenvironment of the upper Messinian (Violanti 1996), was common in many samples of the studied interval (Lozar et al. 2018). Outer neritic taxa were represented by Bulimina aculeata d'Orbigny, 1826, Bulimina minima Tedeschi and Zanmatti, 1957, Cassidulina crassa d'Orbigny, 1839, Cibicidoides pseudoungerianus (Cushman, 1922), Globocassidulina subglobosa 

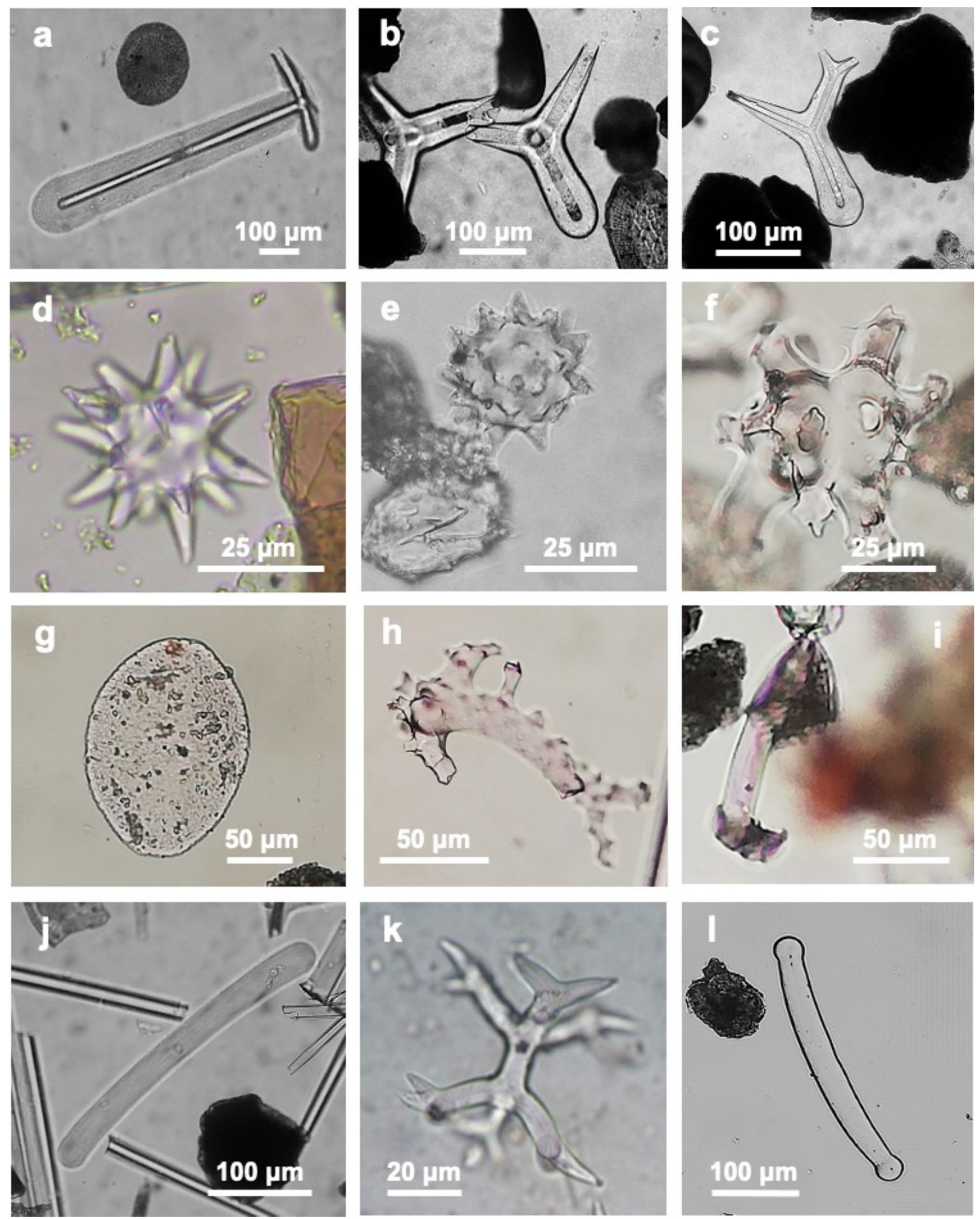
4Fig. 6 Spicules from the Messinian Piedmont Basin: a triaene, with a swollen and round end of the rhabdome; b, $\mathbf{c}$ orto- and anatriaenes with short rhabdome similar to those of the extant Stelletta purpurea; d spheroxyasters typical of the genus Tethya; e spherasters attributed to Chondrilla nucula $\mathbf{f}$ anthospheraster attributed to the living species Diplastrella megastellata $\mathbf{g}$ aspidasters attributable to Penares euastrum; $\mathbf{h}$ desma of a lithistid sponge; $\mathbf{i}$ anisochaela of Mycale; $\mathbf{j}$ strongyles attributed to the Petrosidae family; k amphitriaene of Samus anonymus; $\mathbf{l}$ tylote of Antho (Plocamia) spp.

(Brady, 1881), Hanzawaia boueana (d'Orbigny, 1846), Rectouvigerina sp., Sphaeroidina bulloides d'Orbigny, 1826, Uvigerina peregrina Cushman, 1923 and Uvigerina pygmaea d'Orbigny, 1826, generally with small specimens. As a whole, their percentages range between $10-30 \%$ of the benthic assemblage.

The shallow-water inner neritic forms were almost totally given by a few epifaunal, mainly epiphytic, taxa [Discorbis mira Cushman, 1922, Glabratella sp., Elphidium advenum (Cushman, 1922), Elphidium complanatum (d'Orbigny, 1839), Elphidium macellum (Fichtel and Moll, 1798), and Neoconorbina terquemi (Rzehak, 1888)]. They show rather high fluctuations, with two abundance peaks of about $40 \%$ in samples where abundant sponge spicules and bryozoans also occurred (samples BG 7.1 and BG 8.1). Species typical of sandy inner neritic seafloors, such as Ammonia beccarii (Linnaeus, 1758) or of brackish waters such as Haynesina germanica (Ehrenberg, 1840) (Debenay et al. 2005) were found only in the lowest part of the studied interval (sample BG 7.1), with percentages around or less than $1 \%$, respectively. Miliolids were generally very rare or absent; some small tests of Quinqueloculina seminulum (Linnaeus, 1758), Pyrgo bulloides (d'Orbigny, 1826), Spiroloculina excavata d'Orbigny, 1846, Sigmoilopsis schlumbergeri (Silvestri, 1904) and Sigmoilinita tenuis (Czjzek, 1848) were found only in sample BG 7.1.

At Moncalvo, planktic and benthic foraminifers (Figs. 9 and $11 \mathrm{~b}$ ) were generally small, scarce in the cycle $\mathrm{Mm} 2$ and in the lower part of cycle Mm3, absent in the $>125 \mu \mathrm{m}$ residues of the uppermost part of cycle Mm3. Sporadic juvenile forms were detected in the finer fractions $(63-125 \mu \mathrm{m})$ up to sample MC 130.45. Planktic species were seldom common (Lozar et al. 2018), mainly given by cool-water eutrophic taxa, such as $T$. quinqueloba, which reached percentages of about $30 \%$ in sample MC 131.30 and 20\% in sample MC 130.70, in which T. multiloba showed its last occurrence. An influx of the group G. scitula and G. suterae was detected in sample MC 130.70, from the lower shales of cycle Mm3.

Among benthic foraminifers (Fig. 11b), the shelf infaunal stress-tolerant Bolivina spp. were common in the marls of cycle Mm2, common only in sample MC 130.70 from the marls of cycle Mm3. The extinct B. echinata occurred only in the shales of cycle $\mathrm{Mm} 2$, where it represented almost the total benthic assemblage (Lozar et al. 2018). Outer neritic taxa were present $(<5 \%)$ only in cycle $\mathrm{Mm} 2$. In contrast, they were nearly absent upwards, represented by very few specimens of the same species recorded at Banengo and also by very rare and small Heterolepa cf. dertonensis (Ruscelli, 1953), Planulina ariminensis d'Orbigny, 1826, Textularia conica d'Orbigny, 1839, U. pygmaea, outer neritic to bathyal taxa (Jorissen 1988; Murray 2006). The shallow-water inner neritic forms were absent in the lowermost samples of cycle $\mathrm{Mm} 2$ and became more common upwards. They were represented by epifaunal and/or epiphytic species [Cibicidoides lobatulus (Walker and Jacob, 1798) and D. mira] (Debenay et al. 1996). Benthic taxa of sandy inner neritic seafloors, such as Ammonia spp. and miliolids, were absent.

\section{Bryozoans}

Bryozoan fragments occurred in all the studied samples at Banengo. They are common in cycle $\mathrm{Bm} 3$, particularly abundant in sample BG 8.1, whereas they are scarce in cycle Bm4. At Moncalvo, bryozoans are less common; scarce and small fragments were recognised only in the samples MC 131.10 and MC 130.70, which were particularly rich in sponge spicules. Although locally abundant, the bryozoans are extremely poorly diversified and invariably consisted of internodes, essentially isolated and locally broken, of crisiid cyclostomes. All specimens belong to the genus Crisia Lamouroux, 1812 (Fig. 9) and mostly to the species Crisia fistulosa (Heller 1857). 
a
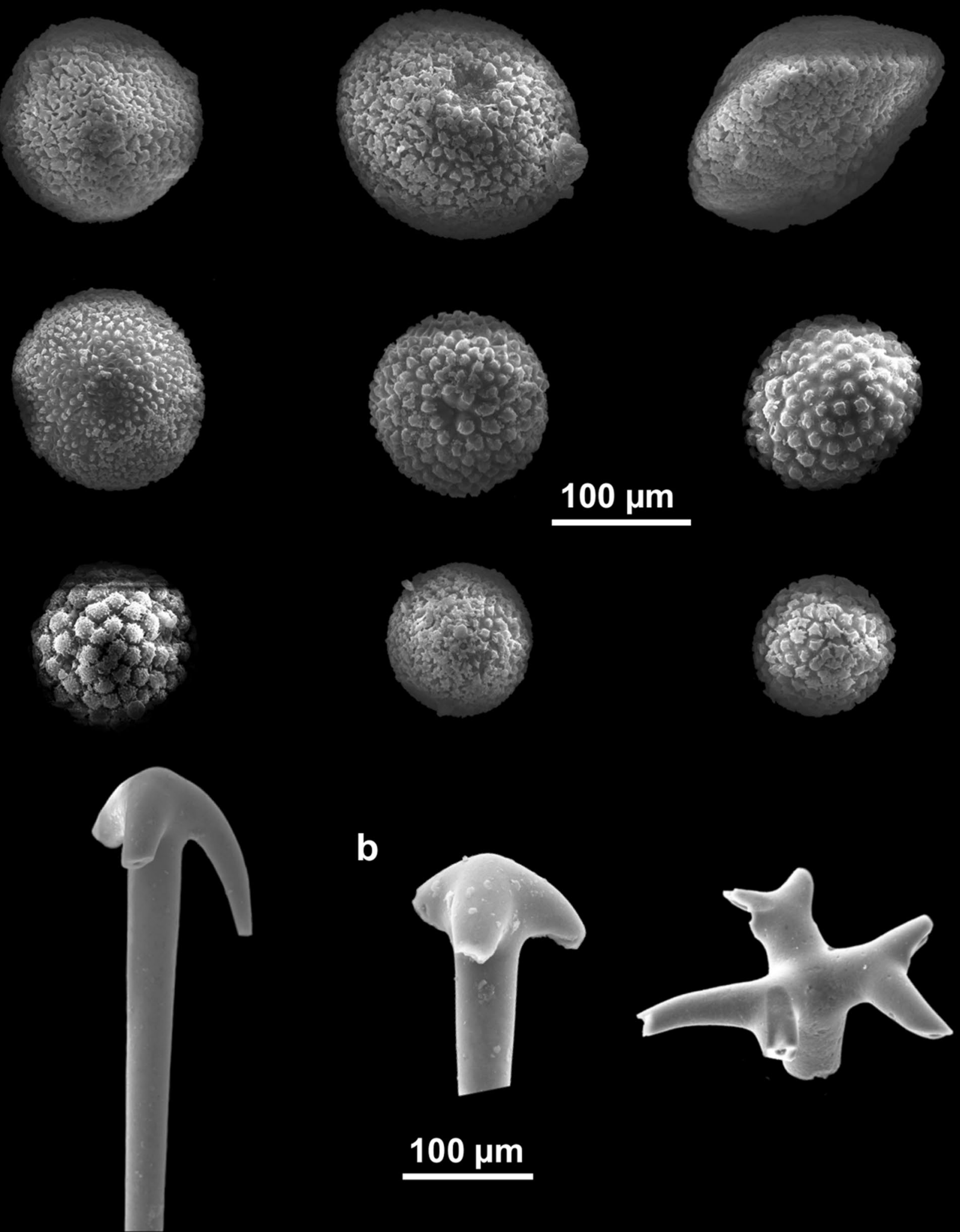

$100 \mu \mathrm{m}$

Fig. 7 Spicules of Geodia from the Messinian Piedmont Basin: a sterrasters; b anatriaenes 


\section{Discussion}

This study of the siliceous sponge spicules of the Messinian succession from the northern margin of the Piedmont Basin is the first analysis of the sponge assemblage for this area, extending the recovery of spongolithic levels, previously described in Piedmont only from late Miocene sediments cropping out in the southern sector of the region (Cappella Montei, Serravalle Scrivia, Alessandria) (Bonci et al. 1996). The siliceous sponge spicules showed some evidence of dissolution, with the typical pitting pattern and the enlargement of the axial canals (Bertolino et al. 2017). This process typically occurs when the spicules are scattered in the sediment, after the death of the sponge (Rützler and Macintyre 1978).

Twenty different morphological types of spicule were identified, eleven of them attributable to genera (or species) of sponges thriving in the present-day Mediterranean Sea. Only two types of spicule are currently missing in the Mediterranean sponge fauna. These spicules were putatively attributed to Stelletta purpurea and Diplastrella megastellata, two species living in warmer seas, i.e. the Red Sea and the Pacific Ocean, and the Caribbean Sea, respectively. These fossil findings testify to the first occurrence of these species in the Mediterranean where they are currently absent.

The three most represented genera, Stelletta, Geodia and Dercitus are characterised today by species with a cushion-shaped morphology. The species belonging to the first two genera live today on sandy seafloors, whereas Dercitus shows a remarkable affinity for rocky shadow habitats where, locally, it assumes a cavity-dwelling habit. Among the less common genera, Tethya, and Chondrilla are massive taxa living today on rocky outcrops, while Alectona is a boring sponge excavating calcareous substrates and Samus is cavity-dwelling (Table 1). Also, other less common taxa (Mycale, Diplastrella, Petrosiidae, Axinellidae) testify to the presence in both areas of hard seafloor substrates.

The spicule abundance is higher in the Moncalvo than the Banengo samples, mainly due to the presence of a large quantity of Geodia sterrasters, which are virtually lacking in the Banengo sediments. Excluding the Geodia spicules, the two sponge assemblages appear similar, with abundant Stelletta and Dercitus which show a strong decrease of about one order of magnitude upwards in both sections, approaching the MSC onset.

Geodia dominance in the Moncalvo sediments suggests a shallow-water palaeoenvironment. Today, the Geodiadominated sponge association is recorded in shallow, sheltered sites like the Stagnone of Marsala (Western Sicily) and the inlet of Porto Cesareo (Western Apulian Coast), characterised by moderate sedimentation and rich trophic conditions (Corriero 1987; Mercurio et al. 2006; Longo et al. 2016; Grech et al. 2020), where large specimens of Geodia cydonium occur in very shallow waters $(0.2-2.5 \mathrm{~m})$. However, it cannot be ruled out that the spicules were transported by currents to the Moncalvo basin from shallower sites. The lack of spicules belonging to this genus in the samples from Banengo is suggestive of a slightly deeper habitat.

Calcareous microfossils confirm the occurrence of high nutrient supply to the water column, as also suggested by the siliceous sponge assemblages. The common eutrophic taxa from the water column (the coccoliths $R$. minuta, $R$. antarctica, C. pelagicus and the foraminifers $G$. scitula and T. quinqueloba) and the opportunistic benthic infaunal foraminifers such as Bolivina spp. and Brizalina spp., widespread in fine sediments rich in organic matter and low in oxygen content (Van der Zwaan 1982), also suggest episodes of high nutrient supply at Banengo and Moncalvo. Phytoplankton (calcareous nannofossils, diatoms) blooms, probably triggered by riverine input (Lozar et al. 2018; Vasiliev et al. 2019; Sabino et al. 2020), as suggested by the abundance of upper photic zone taxa ( $R$. minuta), could be the source of a high amount of biodetritus available to benthic communities. Shallow-water benthic foraminifers were common to abundant and mainly represented by epiphytic forms, living on seaweeds or marine phanerogams (Discorbis spp., Glabratella spp., N. terquemi) (Colom 1974). In contrast, taxa typical of sandy inner neritic seafloors, such as Ammonia spp., and miliolids, such as Quinqueloculina spp., related to well-oxygenated water, were absent or very rare. As a whole, foraminifers suggest deposition on the shelf and exclude a very shallow seafloor, as confirmed by the occurrence of deep photic zone calcareous nannofossil taxa in the assemblage (S. abies in the MSC bioevent). This interpretation is also supported by the lithology (very fine shale and marl) of the studied layers. The absence or rarity of benthic species tolerant or preferential of strong salinity 


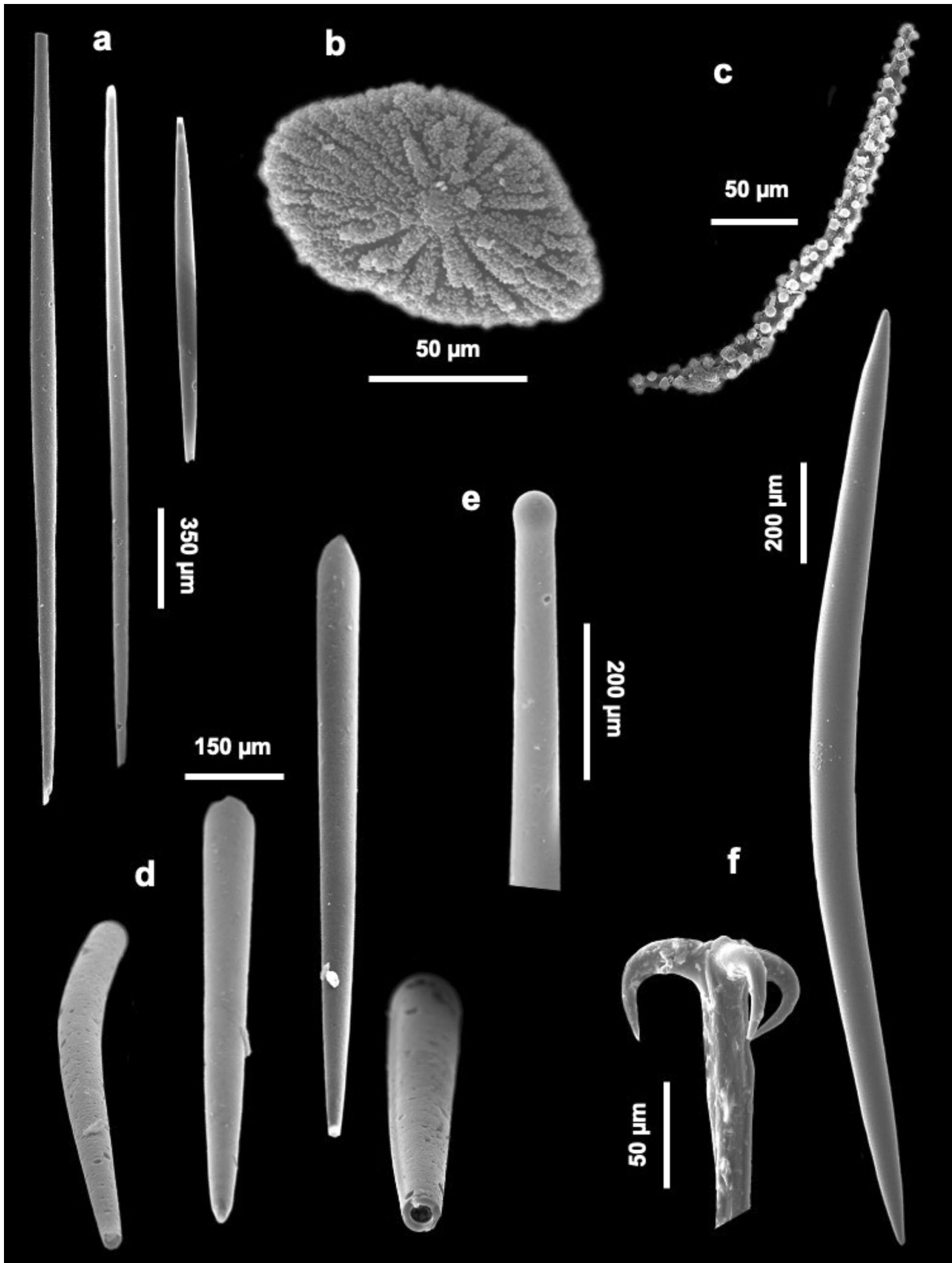


4Fig. 8 Further spicules from the Messinian Piedmont Basin: a strongyloxeas belonging to Tethya; b aspidasters referable to the subfamily Erylinae; c tuberculate oxeas referable to a recent species of Alectona; d short, stout, curved styles probably belonging to species of the genus Axinella; e tylostyles attributable to the family Suberitidae; f anatriaene and oxeas attributed to tetractinellid sponges

variations (i.e. H. germanica) (Debenay et al. 1996), rules out a brackish palaeoenvironment.

At Banengo, the higher percentages of outer neritic benthic taxa than at Moncalvo confirm the rather deeper seafloor suggested by the sponge assemblage. This hypothesis is also supported by the higher abundance of open-marine calcareous nannofossil taxa (C. pelagicus, C. leptoporus). Instead, at Moncalvo these species are rare, and the assemblages are dominated by $R$. minuta, a eutrophic and opportunistic taxon that can thrive in coastal shallow-water environments, support by the presence of sponge Geodia. Moreover, at Moncalvo, calcareous nannofossils were never abundant, probably outcompeted by diatoms, that were absent in Banengo.

Among bryozoans, species of the genus Crisia consist of colonies with internodes a few mm long, articulated by chitinous joints. They arise from a stolonar encrusting base, and the adhesion to the substratum is reinforced through rhizoids (A.R., personal observations).

Crisia fistulosa is an extant Mediterranean species thriving in inner neritic habitats, typically associated with vegetated both hard and soft seafloors, Posidonia meadows and Cystoseira s.l. communities even at very shallow depths (Gautier 1962; Zabala 1986). It has been found commonly associated with other congeners along the coasts of Tunisia (Ben Ismail et al. 2012), the Ionian Sea (Catra et al. 2019; Rosso et al. 2019), in the Ibero-Provençal Basin and the Adriatic Sea (Piazzi et al. 2018). Analogously, abundant crisiid internodes with a dominance of $C$. fistulosa have been reported in fossil Posidonia-rich layers in the late Pliocene of Rhodes (Moissette 2013). The occurrence of Crisia internodes is thus consistent with the evidence provided by benthic foraminifers for seagrass meadows. After death, colonies are usually soon disarticulated and segments potentially transported away and deposited in deeper water settings, or trapped in the sediment baffled at the plant base. The occurrence in the collected material of rarely worn fragments and some still connected internodes (Fig. 9e) could indicate a rapid within habitat burial after a possible local elaboration and redistribution of specimens on the seafloor. However, some still connected internodes (Fig. 9e) could indicate a rapid within habitat burial.
As a whole, microfossil assemblages of the Banengo and Moncalvo sections suggest soft-seafloor rather shallow shelf palaeoenvironments, probably referable to the deep inner neritic zone, in a protected bay at Moncalvo, in the area that in the early Pliocene will be the "Pliocene Moncalvo Gulf” (Dela Pierre et al. 2003). A slightly deeper and open palaeoenvironment can be proposed for Banengo, on the basis of the rather higher abundance of outer neritic, open shelf taxa both among calcareous nannofossils and foraminifers. In the two sites, common epiphytic foraminifers and bryozoans point to vegetated either rocky or sedimentcovered seafloors colonised by Posidonia, or algal meadows. Moreover, a diversified group of sponges related to hard, carbonate substrata, suggest the presence, in both sites of rocky outcrops.

\section{Conclusion}

The study on the Messinian succession of the Monferrato (Piedmont, Northwestern Italy) is providing new significant data on the palaeoenvironmental evolution of the northern part of the Mediterranean basin at the onset of the MSC. Herein, integrated micropalaeontological analyses provide insights into the palaeoenvironmental settings just before the onset of the MSC at the northern margin of the TPB. The analysis of sponge spicules within the Messinian sediments and that of the concurrent nanno- and micro-fossil communities reveals the diversity of the community and provides data on the conditions present in the area during the late Messinian time interval. The different taxonomic groups appear to react differently to changing palaeoenvironmental parameters, such as riverine input, silica and nutrient availability, and probably increased seasonality. Calcareous microfossils, and planktic and benthic foraminifers seem to be the more affected group by the rising stress conditions, decreasing in abundance and diversity, compared to calcareous nannofossils. In contrast, siliceous forms, such as diatoms and sponges, flourished under the same conditions, probably with the former responding to increased nutrient supply, and the latter to organic detritus availability.

Our data clearly indicate a substantial similarity between pre-MSC and recent coastal sponge fauna. This similarity could be due to the persistence of the pre-MSC fauna in refuge zones within the Mediterranean basin or to a recolonisation from the neighbouring Atlantic area (Montenat et al. 1980). 


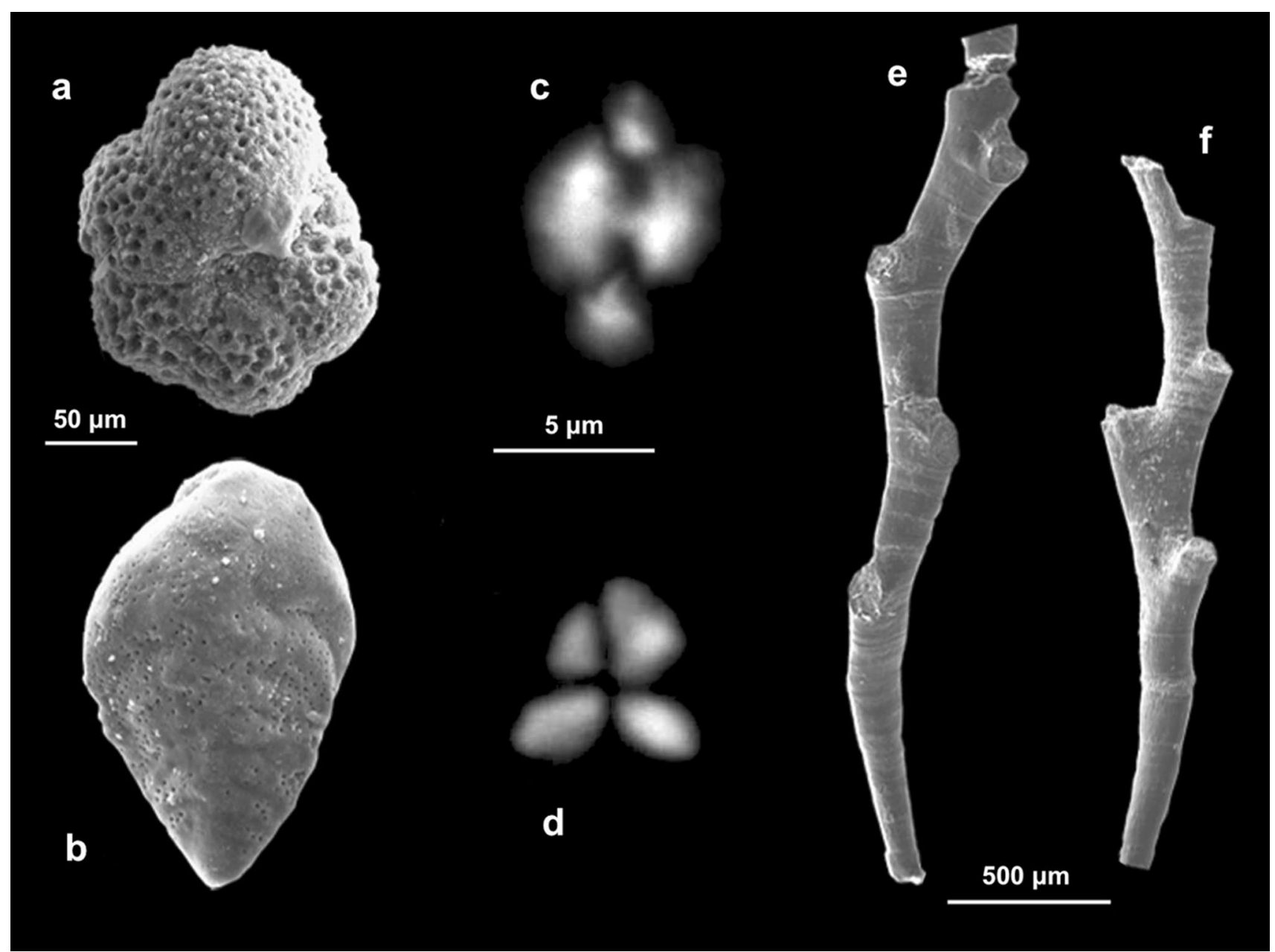

Fig. 9 Calcareous microfossils. The foraminifers a Turborotalita quinqueloba, Banengo, sample BG 12.1, b Brizalina dilatata, Moncalvo, sample $131.30 \mathrm{~m}$, the nannofossils, c Helicosphaera carteri,
Banengo, sample BG 7.2, d Sphenalithus abies, Banengo, sample BG 8.1, and $\mathbf{e}, \mathbf{f}$ the bryozoan Crisia fistulosa, Banengo, sample BG 8.1 
a

\section{BANENGO Calcareous nannofossils}

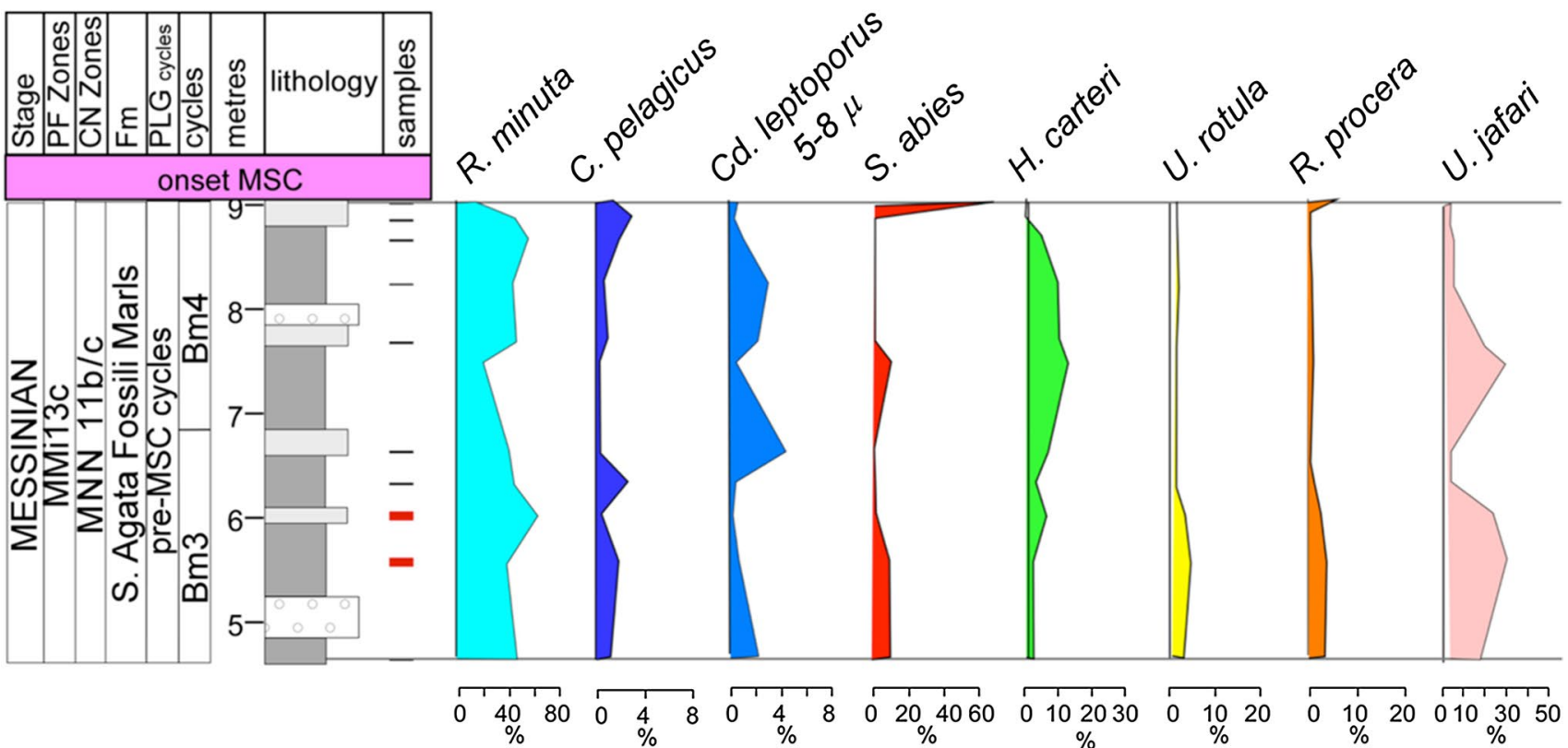

- sponge spicules

shale

marls

calcarenite

b

\section{BANENGO

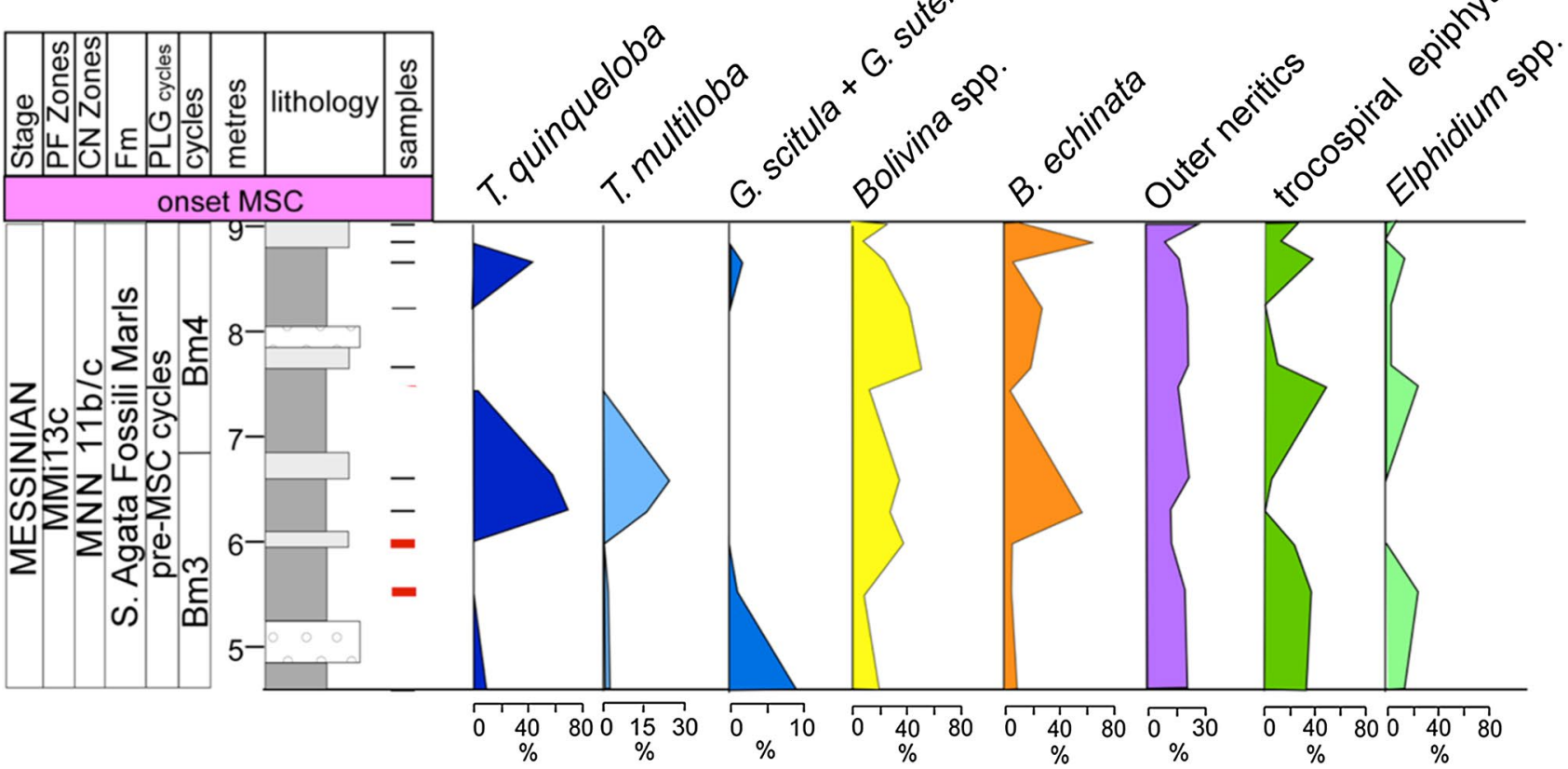

Fig. 10 a Banengo section. Chronostratigraphy, calcareous plankton biostratigraphy, lithostratigraphy, sample location, and the percentage variation of main calcareous nannofossil taxa. Spicule content evidenced with red hyphen. b Banengo section. Chronostratigraphy, cal- careous plankton biostratigraphy, lithostratigraphy, sample location, and the percentage variation of main planktic and benthic foraminiferal taxa. Spicule content evidenced with red hyphen. Legend as in Fig. 10a 
a

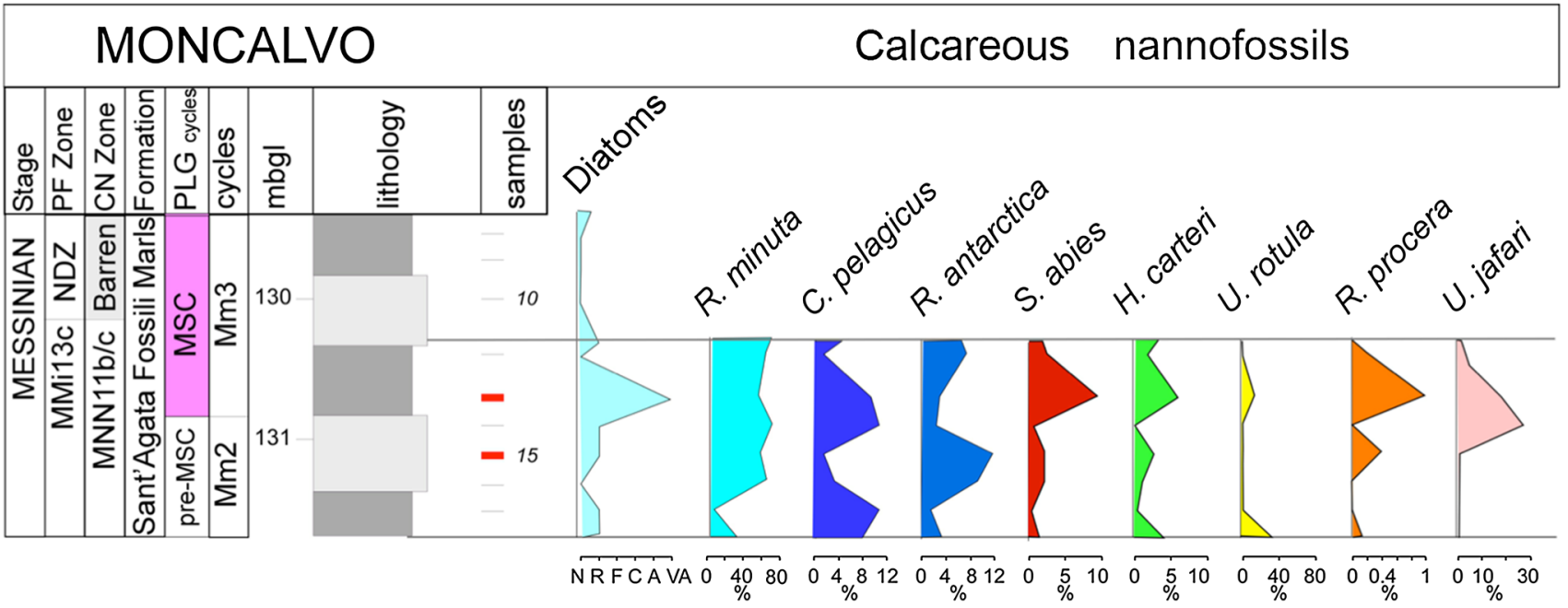

b

MONCALVO

Foraminifers

benthic

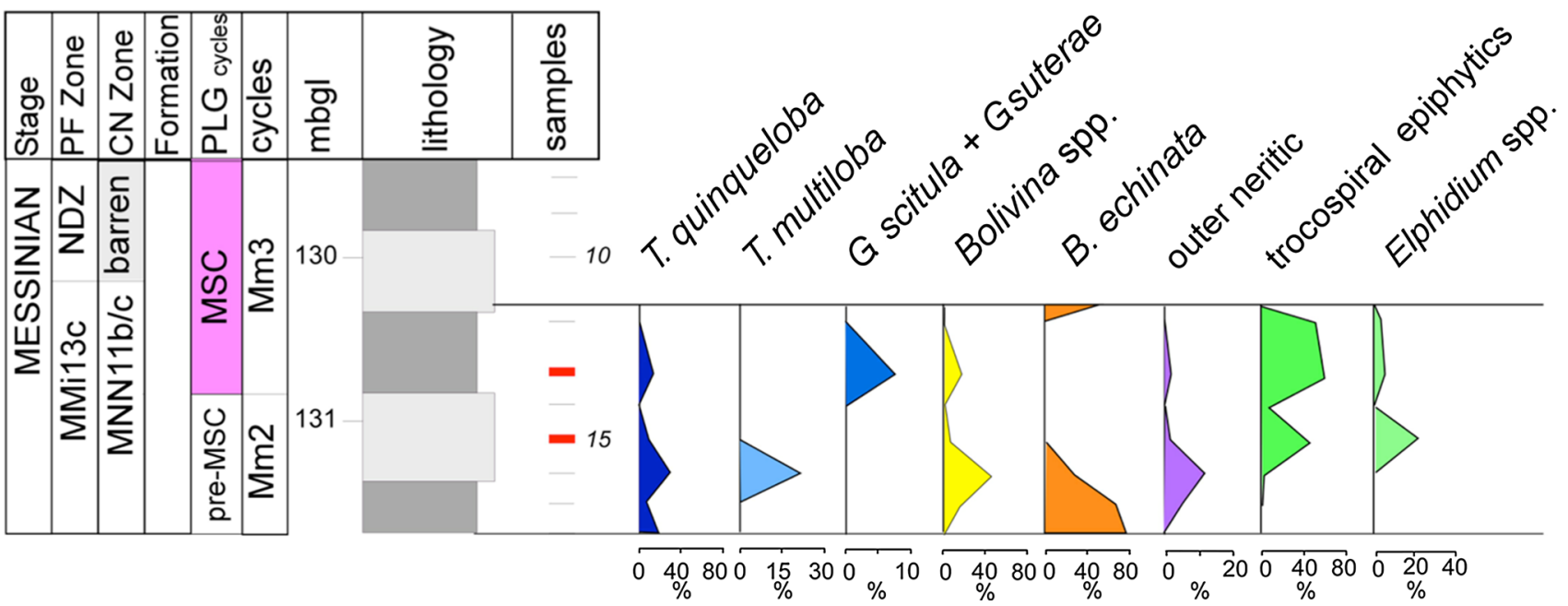

Fig. 11 a Moncalvo section. Chronostratigraphy, calcareous plankton biostratigraphy, lithostratigraphy, sample location, and the percentage variation of main calcareous nannofossil taxa. The occurrence of diatoms is also reported. Legend as in Fig. 10a. Spicule content evidenced with a red hyphen. b Moncalvo section. Chronostratigra-

Acknowledgements Many thanks to Dr Carlo Avignolo for the help in spicule analysis and Dr Simona Cavagna, for assistance in SEM analyses of calcareous microfossils at the Earth Science Department, Turin University. We are grateful to the Editor (Maurice Tucker) and the two reviewers for their excellent advice. A. Rosso was funded by the University of Catania through "PiaCeRi - Piano Incentivi per la Ricerca di Ateneo 2020-22, linea di intervento 2". phy, calcareous plankton biostratigraphy, lithostratigraphy, sample location, and the percentage variation of main planktic and benthic foraminiferal taxa. Spicule content evidenced with a red hyphen. Legend as in Fig. 10a

\section{References}

Ben Ismail D, Raboui L, Diawara M, Ben Hassine OK (2012) The Bryozoan assemblages and their relationship with certain environmental factors along the shallow and subtidal Tunisian coasts. Cah Biol Mar 53:231-242

Bernardi E (2013) Integrated stratigraphy of the Northernmost record of the Messinian Salinity Crisis: New insight from the Tertiary Piedmont Basin. Doctoral Thesis, Turin University. 
Bertolino M, Calcinai B, Cattaneo-Vietti R, Cerrano C, Lafratta A, Pansini M, Pica D, Bavestrello G (2014) Stability of the sponge assemblage of Mediterranean coralligenous concretions along a millennial time span. Mar Ecol 35(2):149-158. https://doi. org/10.1111/maec.12063

Bertolino M, Cattaneo-Vietti R, Costa G, Pansini M, Fraschetti S, Bavestrello G (2017) Have climate changes driven the diversity of a Mediterranean coralligenous sponge assemblage on a millennial timescale? Palaeogeogr Palaeoclimatol Palaeoecol 487:355-363. https://doi.org/10.1016/j.palaeo.2017.09.020

Blanc-Valleron MM, Pierre C, Caulet JP, Caruso A, Rouchy JM, Cespuglio G, Sprovieri R, Pestrea S, Di Stefano E (2002) Sedimentary, stable isotope and micropaleontological records of paleoceanographic change in the Messinian Tripoli Formation (Sicily, Italy). Palaeogeogr Palaeoclimatol Palaeoecol 185:255286. https://doi.org/10.1016/S0031-0182(02)00302-4

Bonci MC (1995) L'associazione a Diatomee del Miocene superiore di Cappella Montei (Alessandria). BSPI 34(2):163-191

Bonci MC, Fanucci F, Pirini Radrizzani C, Rizzi A, Tedeschi D (1991) I livelli diatomitici della successione miocenica di Cappella Montei (area di Serravalle Scrivia, Bacino di Alessandria). BSPI 30(3):301-381

Bonci MC, Magnino G, Pirini Radrizzani C, Pronzato R (1996) Finding of Geodia (Demospongiae) sterrasters in the Late Miocene of Cappella Montei (Alessandria) and comparison with living forms. BSPI 35(3):245-256

Brimaud C, Vachard D (1986) Les spongiaires siliceux du Tortonien des Betiques (Miocene de l'Espagne du Sud): especes nouvelles ou peu connues. I: Choristides et Lithistides. Bull Mus Natl Hist Nat Paris 8(3):293-341

Catra M, Alongi G, Leonardi R, Negri M, Sanfilippo R, Sciuto F, Serio D, Viola A, Rosso A (2019) Degradation of a photophilic algal community and its associated fauna from eastern Sicily (Mediterranean Sea). Mediterr Mar Sci 20(1):74-89. https://doi. org/10.12681/mms. 17765

Cita MB, Wright RC, Ryan WBF, Longinelli A (1978) Messinian paleoenvironments. In: Kidd RB, Worstell PJ (eds) Initial reports of the deep sea drilling project. Texas University, Texas, pp 1003-1035

Colom G (1974) Foraminiferos ibericos. Introducion al estudio de las especies bentonicas recientes. Investig Pesquer 38(1):1-245

Corriero G (1987) The sponge fauna from the Stagnone of Marsala (Sicily): taxonomic and ecological observations. Boll Mus Ist Biol Univ Genova 53:101-113

Debenay JP, Millet B, Angelidis M (2005) Relations between foraminiferal assemblages and hydrodinamics in the Gulf of Kalloni. Greece J Foraminiferal Res 35(4):327-343. https://doi. org/10.2113/35.4.327

Debenay JP, Pawlowski J, Decrouez D (1996) Les foraminiféres actuels. Masson, Paris

Dela Pierre F, Bernardi E, Cavagna S, Clari P, Gennari R, Irace A, Lozar F, Lugli S, Manzi V, Natalicchio M, Roveri M, Violanti D (2011) The record of the Messinian salinity crisis in the Tertiary Piedmont Basin (NW Italy): The Alba section revisited. Palaeogeogr Palaeoclimatol Palaeoecol 310:238-255. https:// doi.org/10.1016/j.palaeo.2011.07.017

Dela Pierre F, Clari P, Natalicchio M, Ferrando S, Giustetto R, Lozar F, Lugli S, Manzi V, Roveri M, Violanti D (2014) Flocculent layers and bacterial mats in the mudstone interbeds of the Primary Lower Gypsum unit (Tertiary Piedmont Basin, NW Italy): Archives of palaeoenvironmental changes during the Messinian salinity crisis. Mar Geol 355:71-87. https://doi.org/10.1016/j. margeo.2014.05.010

Dela Pierre F, Natalicchio M, Ferrando S, Giustetto R, Birgel D, Carnevale G, Gier S, Lozar F, Marabello D, Peckmann J (2015) Are the large filamentous microfossils preserved in Messinian gypsum colorless sulfide-oxidising bacteria? Geol 43:855-858. https://doi.org/10.1130/G37018.1

Dela Pierre F, Piana F, Fioraso G, Boano P, Bicchi E, Forno MG, Violanti D, Balestro G, Clari P, d'Atri A, De Luca D, Morelli M, Ruffini R (2003) Note illustrative della Carta Geologica d'Italia alla scala 1:50.000, Foglio 157 Torino. APAT Dipart Dif Suolo: 1-147.

Dendy A (1905) Report on the sponges collected by Professor Herdman, at Ceylon, in 1902. In: Herdman WA ed. Report to the government of ceylon on the pearl oyster fisheries of the gulf of manaar. 3 (Supplement 18). Royal Society, London, pp 57-246

Flecker R, Krijgsman W, Capella W, de Castro MC, Dmitrieva E, Mayser JP, Marzocchi A, Modestou S, Ochoa D, Simon D, Tulbure M, van den Berg B, van der Schee M, de Lange G, Ellam R, Govers R, Gutjahr M, Hilgen F, Kouwenhoven T, Lofi J, Meijer P, Sierro FJ, Bachiri N, Barhoun N, Alami AC, Chacon B, Flores JA, Gregory J, Howard J, Lunt D, Ochoa M, Pancost R, Vincent S, Yousfi MZ (2015) Evolution of the Late Miocene Mediterranean-Atlantic gateways and their impact on regional and global environmental change. Earth-Sci Rev 150:365-392. https://doi.org/10.1016/j. earscirev.2015.08.007

Frisone V, Pisera A, Hajdu E, Preto N, Zorzi F, Zorzin R (2014) Isolated spicules of Demospongiae from Mt. Duello (Eocene, Lessini Mts., northern Italy): preservation, taxonomy, and depositional environment. Facies 60(4):883-904. https://doi.org/10.1007/ s10347-014-0407-3

Gautier YV (1962) Recherches écologiques sur les Bryozoaires chilostomes en Méditerranée occidentale. Rec trav Stat Mar Endoume 38:1-434

Gennari R, Lozar F, Turco E, Dela Pierre F, Manzi V, Natalicchio M, Lugli S, Roveri M, Schreiber BC, Taviani M (2018) Integrated stratigraphy and paleoceanographic evolution of the pre-evaporitic phase of the Messinian salinity crisis in the Eastern Mediterranean as recorded in the Tokhni section (Cyprus island). Newsl Stratigr 51(1):33-55

Gennari R, Manzi V, Angeletti L, Bertini A, Biffi U, Ceregato A, Faranda C, Gliozzi E, Lugli S, Menichetti E, Rosso A, Roveri M, Taviani M (2013) A shallow water record of the onset of the Messinian salinity crisis in the Adriatic foredeep (Legnagnone section, Northern Apennines). Palaeogeogr Palaeoclimatol Palaeoecol 386:145-164. https://doi.org/10.1016/j.palae o.2013.05.015

Grech D, van de Poll B, Bertolino M, Rosso A, Guala I (2020) Massive stranding event revealed the occurrence of an overlooked sponge ecosystem engineer in Sardinia (Italy, Western Mediterranean). Mar Biodivers 50(5):82. https://doi.org/10.1007/s1252 6-020-01105-4

Hemleben C, Spindler M, Anderson OR (1989) Modern planktonic foraminifera. Springer, Berlin, New York

Hinde GJ, Holmes WM (1892) On the sponge-remains in the lower tertiary strata near Oamaru, Otago, New Zealand. Zool J Linnean Soc 24(151):177-262

Hoffmann R, Bitner MA, Pisera A, Jäger M, Auer G, Giraldo-Gómez V, Koci' T, Buckeridge J, Mueller M, Stevens K, Schneider S (2020) Late Miocene biota from the Abad Member of the CarbonerasNijar Basin (Spain, Andalusia): a bathyal fossil assemblage predating the Messinian salinity crisis. Geobios 59:1-28. https://doi. org/10.1016/j.geobios.2020.03.002

Hsü KJ, Cita MB, Ryan WBF (1973) The origin of the Mediterranean evaporites. In: Ryan WBF, Hsü KJ et al (eds) Initial report of deep sea drilling program. Government Printing Office, Washington DC, pp 1203-1231

Iaccarino S (1985) Mediterranean Miocene and Pliocene planktic foraminifera. In: Bolli HM, Saunders JB, Perch Nielsen K (eds) Plankton stratigraphy. Cambridge University Press, Cambridge, pp 283-314 
Irace A, Dela Pierre F, Clari P (2005) "Normal" and "chaotic" deposits in the Messinian Gessoso-solfifera Fm. at the north-eastern border of the Langhe domain (Tertiary Piedmont Basin). Boll Soc Geol Ital 4:77-85

Jorissen FJ (1988) Benthic foraminifera from the Adriatic Sea: principles of phenotypic variation. Utrecht Micropaleont Bull 37:1-174

Kouwenhoven TJ, Morigi C, Negri A, Giunta S, Krijgsman W, Rouchy JM (2006) Paleoenvironmental evolution of the eastern Mediterranean during the Messinian: Constraints from integrated microfossil data of the Pissouri Basin (Cyprus). Mar Micropaleont 60:17-44. https://doi.org/10.1016/j.marmicro.2006.02.005

Krijgsman W, Hilgen FJ, Raffi I, Sierro FJ, Wilson DS (1999) Chronology, causes and progression of the Messinian salinity crises. Nature 400:652-655. https://doi.org/10.1038/23231

Longo C, Cardone F, Mercurio M, Nonnis Marzano C, Pierri C, Corriero G (2016) Spatial and temporal distributions of the sponge fauna in southern Italian lagoon systems. Med Mar Sci 17(1):174189. https://doi.org/10.12681/mms.1426

Lourens LJ, Hilgen FJ, Shackleton NJ, Laskar J, Wilson D (2004) The neogene period. In: Gradstein F, Ogg J, Smith A (eds) A geologic time scale 2004. Cambridge University Press, Cambridge, pp 409-440

Lozar F, Negri A (2019) A review of basin-wide calcareous nannofossil bioevents in the Mediterranean at the onset of the Messinian salinity crisis. Mar Micropal. https://doi.org/10.1016/j.marmi cro.2019.101752

Lozar F, Violanti D, Bernardi E, Dela Pierre F, Natalicchio M (2018) Identifying the onset of the Messinian salinity crisis: a reassessment of the biochronostratigraphic tools (Piedmont Basin, NW Italy). Newsl Stratigr 51(1):11-31

Lozar F, Violanti D, Dela Pierre F, Bernard E, Cavagna S, Clari P, Irace A, Martinetto E, Trenkwalder S (2010) Calcareous nannofossils and foraminifers herald the Messinian salinity crisis: the Pollenzo section (Alba, Cuneo; NW Italy). Géobios 43:21-32. https://doi. org/10.1016/j.geobios.2009.07.002

Łukowiak M, Pisera A, Schlögl J (2014) Bathyal sponges from the late Early Miocene of the Vienna Basin (Central Paratethys, Slovakia). Paläontol Z 88(3):263-277. https://doi.org/10.1007/s1254 2-013-0197-x

Łukowiak M, Pisera A, Stefanska T (2019) Uncovering the hidden diversity of Paleogene sponge fauna of the East European Platform through reassessment of the record of isolated spicules. Acta Palaeontol Pol 64(4):871-895

Mancini AM, Gennari R, Ziveri P, Mortyn PG, Stolwijk DJ, Lozar F (2020) Calcareous nannofossil and foraminiferal trace element records in the Sorbas Basin: a new piece of the Messinian Salinity Crisis onset puzzle. Palaeogeogr Palaeoclimatol Palaeoecol. https ://doi.org/10.1016/j.palaeo.2020.109796

Manzi V, Gennari R, Hilgen F, Krijgsman W, Lugli S, Roveri M, Sierro FJ (2013) Age refinement of the Messinian salinity crisis onset in the Mediterranean. Terra Nova 25:315-322. https://doi. org/10.1111/ter. 12038

Manzi V, Roveri M, Gennari R, Bertini A, Biffi U, Giunta S, Iaccarino SM, Lanci L, Lugli S, Negri A, Riva A, Rossi ME, Taviani M (2007) The deep-water counterpart of the Messinian Lower Evaporites in the Apennine foredeep: the Fanantello section (Northern Apennines, Italy). Palaeogeogr, Palaeoclimatol, Palaeoecol 251:470-499. https://doi.org/10.1016/j.palaeo.2007.04.012

Matteucci R, Russo A (2005) The Middle Eocene siliceous sponges from Val di Chiampo (Lessini Mountains, northern Italy). In: Fugagnoli A, Basso D eds. Atti della Giornata di Studi Paleontologici in onore della prof. Carmen Broglio Loriga (Ferrara, 18 giugno 2004, pp 51-62. Ann Univ Ferrara, special issue.

Matteucci R, Russo A (2012) The Italian Cenozoic siliceous sponges: a review, with a revision of the Catullo (1856) collection. J Mediterr Earth Sci 4:1-15. https://doi.org/10.3304/JMES.2012.001
Mercurio M, Longo C, Corriero G (2006) Modificazioni della fauna a poriferi nell'insenatura della Strea di Porto Cesareo (Mar Ionio). Biol Mar Mediterr 13(1):257-260

Merle D, Lauriat-Rage A, Gaudant J, Pestrea S, Courme-Rault MD, Zorn I, Blanc-Valleron M-M, Rouchy JM, Orszag-Sperber F, Krijgsman W (2002) Les paléopeuplements marins du Messinien pré-evaporitique de Pissouri (Chypre, Méditerranée orientale): aspects paléoécologiques de la crise de salinité messinienne. Geodiversitas 24:669-689

Moissette P (2013) Seagrass-Associated Bryozoan Communities from the Late Pliocene of the Island of Rhodes (Greece). In: Ernst A, Schäfer P, Scholz J eds. Bryozoan Studies 2010 proceedings of the 15th IBA conference, 2010 Kiel, Germany. Lecture notes in earth system sciences, pp 187-201. Springer, Berlin, Heidelberg. Doi: https://doi.org/10.1007/978-3-642-16411-8_13

Montenat C, Ott d'Estevou P, Plaziat JC, Chapel J (1980) La signification des faunes marines contemporaines des evaporites messiniennes dans le Sud-Est d'Espagne. Geol Medit 7:81-90

Morigi C, Negri A, Giunta S, Kouwenhoven T, Krijgsman W, BlancValleron MM, Orszag-Sperber F, Rouchy JM (2007) Integrated quantitative biostratigraphy of the latest Tortonian-early Messinian Pissouri section (Cyprus): An evaluation of calcareous plankton bioevents. Géobios 40:267-279. https://doi.org/10.1016/j. geobios.2007.02.002

Murray JW (2006) Ecology and applications of benthic foraminifera. Cambridge University Press, Cambridge

Pellegrino L, Abe K, Gennari R, Lozar F, Dela Pierre F, Natalicchio M, Mikami Y, Jordan RW, Carnevale G (2020a) Integrated micropaleontological study of the Messinian diatomaceous deposits of the Monferrato Arc (Piedmont basin, NW Italy): new insights into the paleoceanographic evolution of the northernmost Mediterranean region. Mar Micropaleontol 160:1-19. https://doi.org/10.1016/j. marmicro.2020.101910

Pellegrino L, Dela Pierre F, Jordan RJ, Abe K, Mikami Y, Gennari R, Lozar F, Carnevale G (2020b) The upper Miocene diatomaceous sediments of the northernmost Mediterranean region: a laminascale investigation of an overlooked palaeoceanographic archive. Sedimentol 67:3389-3421. https://doi.org/10.1111/sed.12748

Piazzi L, Bonaviri C, Castelli A, Ceccherelli G, Costa G, Curini-Galletti M, Langeneck J, Manconi R, Montefalcone M, Pipitone C, Rosso A, Pinna S (2018) Biodiversity in canopy-forming algae: structure and spatial variability of the Mediterranean Cystoseira assemblages. Estuar Coast Shelf Sci 207:132-141. https://doi. org/10.1016/j.ecss.2018.04.001

Pisera A, Cachao M, Da Silva CM (2006) Siliceous sponge spicules from the Miocene Mem Moniz marls (Portugal) and their environmental significance. Riv Ital Paleo Stratigr 112(2):287-299

Raffi I, Mozzato CA, Fornaciari E, Hilgen FJ, Rio D (2003) Late Miocene calcareous nannofossil biostratigraphy and astrobiochronology for the Mediterranean region. Micropaleont 49:1-26. https:// doi.org/10.2113/49.1.1

Rosso A, Sanfilippo R, Sciuto F, Serio D, Catra M, Alongi G, Viola A, Leonardi R (2019) Preliminary information on bryozoans associated with selected Cystoseira communities from Sicily (Mediterranean). In: Schmidt R, Reid C, Gordon DP, Walker-Smith G, Martin S, Percival I eds. Bryozoan Studies 2016. Memoirs of the Australasian Association of Palaeontologists. Proceedings of the Seventeenth International Bryozoology Association Conference, 10-15 April 2016, Melbourne, Australia pp 115-129

Roveri M, Flecker R, Krijgsman W, Lofi J, Lugl S, Manzi V, Sierro FJ, Bertini A, Camerlenghi A, de Lange GJ, Govers R, Hilgen FJ, Hübscher C, Meijer PT, Stoica M (2014) The Messinian Salinity Crisis: past and future of a great challenge for marine sciences. Mar Geol 352:25-58. https://doi.org/10.1016/j.marge o.2014.02.002 
Roveri M, Landuzzi A, Bassetti MA, Lugli S, Manzi V, Ricci Lucchi F, Vai GB (2004) The record of the Messinian events in the northern Apennines foredeep basins. 32nd International Geological Congress Field Trip Guide Book-B19, Florence, Italy, August 20-28, 14 pp.

Roveri M, Manzi V, Bassetti MA, Merini M, Ricci Lucchi F (1998) Stratigraphy of the Messinian post-evaporitic stage in eastern Romagna (northern Apennines, Italy). Giorn Geol 60:119-142

Rützler K, Macintyre IG (1978) Siliceous sponge spicules in coral reef sediments. Mar Biol 49(2):147-159

Sabino M, Schefuss E, Natalicchio M, Dela Pierre F, Birgel D, Bortels D, Schnetger B, Peckmann JL (2020) Climatic and hydrologic variability in the northern Mediterranean across the onset of the Messinian salinity crisis. Palaeogeogr Palaeoclimatol, Palaeoecol 545:109632. https://doi.org/10.1016/j.palaeo.2020.109632

Sierro FJ, Hilgen FJ, Krijgsman W, Flores JA (2001) The Abad composite (SE Spain): a Mediterranean and global reference section for the Messinian. Palaeogeogr Palaeoclimatol Palaeoecol 168:141-169. https://doi.org/10.1016/S0031-0182(00)00253-4

Suc JP, Violanti D, Londeix L, Poumot C, Robert C, Clauzon G, Gautier F, Turon JL, Ferrier J, Chikhi H, Cambon G (1995) Evolution of the Messinian Mediterranean environments: the Tripoli Formation at Capodarso (Sicily, Italy). Rev Palaeobot Palynol 87:51-79. https://doi.org/10.1016/0034-6667(94)00144-9

Thiele J (1900) Kieselschwämme von Ternate. I. Abhandlungen herausgegeben von der Senckenbergischen naturforschenden Gesellschaft, Frankfurt, pp 19-80

Thomas PA (1979) Studies on sponges of the Mozambique Channel. I. Sponges of the Inhaca Island. II. Sponges of Mambone and Paradise Islands. Annales du Musée royal de l'Afrique centrale. Sciences zoologiques, Tervuren, pp 1-73.

Van der Zwaan GJ (1982) Paleoecology of late miocene mediterranean foraminifera. Utrecht Micropaleont Bull 25:1-170

Van Soest RWM, Boury-Esnault N, Hooper JNA, Rutzler K, de Voogd NJ, Alvarez de Glasby B, Hajdu E, Pisera AB, Manconi R, Schoenberg C, Janussen D, Tabachnick KR, Klautau M, Picton B, Kelly M, Vacelet J, Dohrmann M, Diaz CM, Cardenas P (2020) World Porifera database. Accessed Aug 2020 http://www.marin especies.org/porifera/.
Van Soest RWM, Boury-Esnault N, Vacelet J, Dohrmann M, Erpenbeck D, De Voogd NJ, Santodomingo N, Vanhoorne B, Kelly M, Hooper JNA (2012) Global diversity of sponges (Porifera). PLoS One 7(4):e35105. https://doi.org/10.1371/journal.pone.0035105

Vasiliev I, Karakitsios V, Bouloubassi I, Agiadi K, Kontakiotis G, Antonarakou A, Triantaphyllou M, Gogou A, Kafousia N, de Rafélis M, Zarkogiannis S, Kaczmar F, Parinos C, Pasadakis N (2019) Large sea surface temperature, salinity, and productivity preservation changes preceding the onset of the Messinian Salinity Crisis in the Eastern Mediterranean Sea. Paleoceanogr Paleoclimatol 34:182-202. https://doi.org/10.1029/2018PA003438

Violanti D (1996) Taxonomy and distribution of Bulimina echinata and relations with the Messinian paleoenvironment. Boll Soc Paleontol It 3:243-253

Violanti D, Gallo LM, Rizzi A (2007) Foraminiferal assemblages of the Bric della Muda laminites (Nizza Monferrato, Piedmont): Proxies of cyclic paleoenvironmental changes in the Lower Messinian of Northwestern Italy. Geobios 40:281-290. https:// doi.org/10.1016/j.geobios.2006.11.003

Violanti D, Lozar F, Dela Pierre F, Natalicchio M, Bernardi E, Clari P, Cavagna S (2013) Stress tolerant microfossils of a Messinian succession from the northern Mediterranean basin (Pollenzo section, Piedmont, Northwestern Italy). Boll Soc Paleontol It 52(1):45-54

von Lendenfeld R (1890) Das System der Spongien. Abh Senckenb naturforsc Gesellschaft 16(2):361-439

Wade BS, Bown PR (2006) Calcareous nannofossils in extreme environment: the Messinian Salinity Crisis, Polemi Basin, Cyprus. Palaeogeogr Palaeoclimatol Palaeoecol 233:271-286. https://doi. org/10.1016/j.palaeo.2005.10.007

Zabala M (1986) Fauna dels Briozous dels Països Catalans. Barcelona. Institut d'Estudis Catalans, Secció de Ciències 84:1-836 